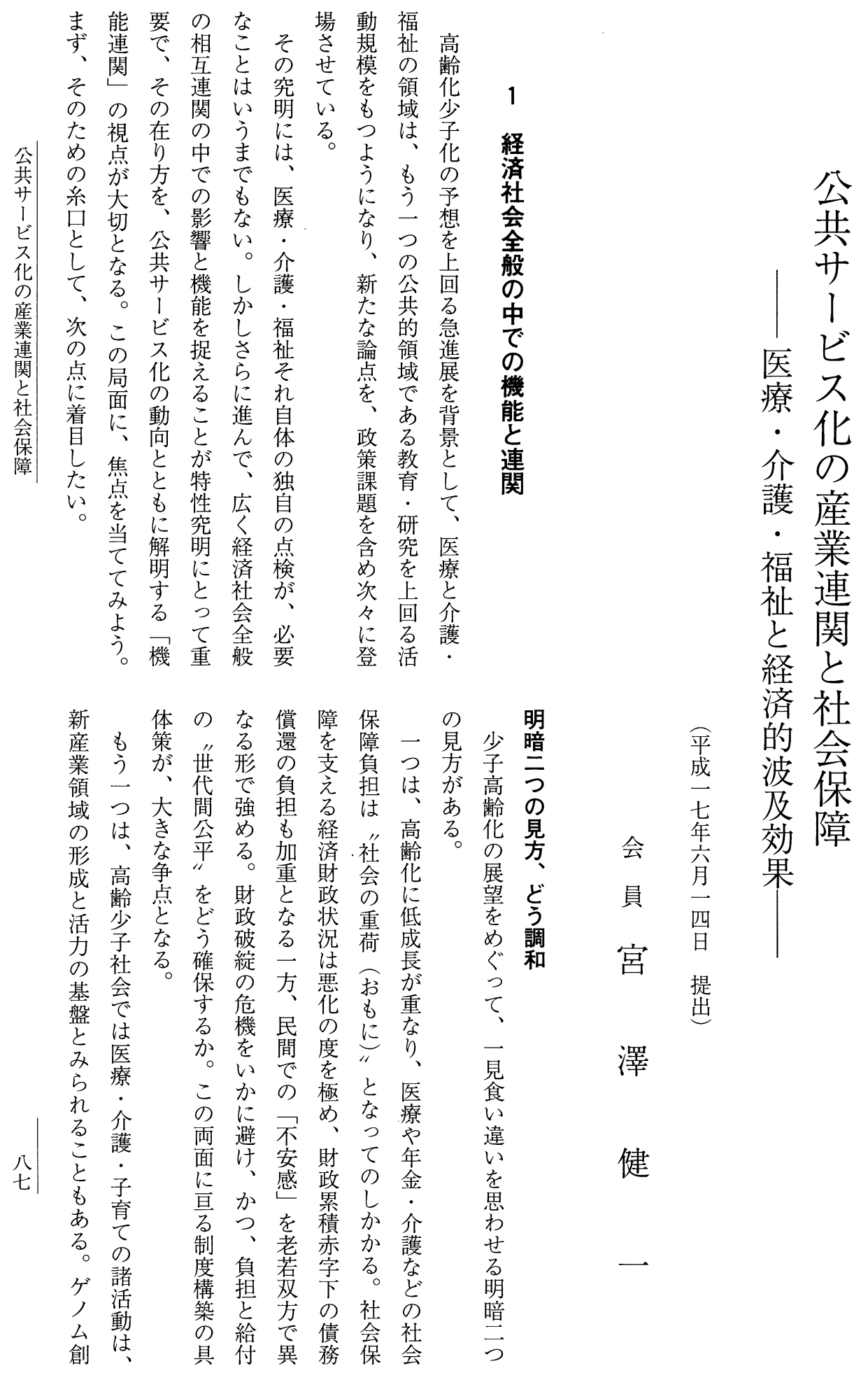




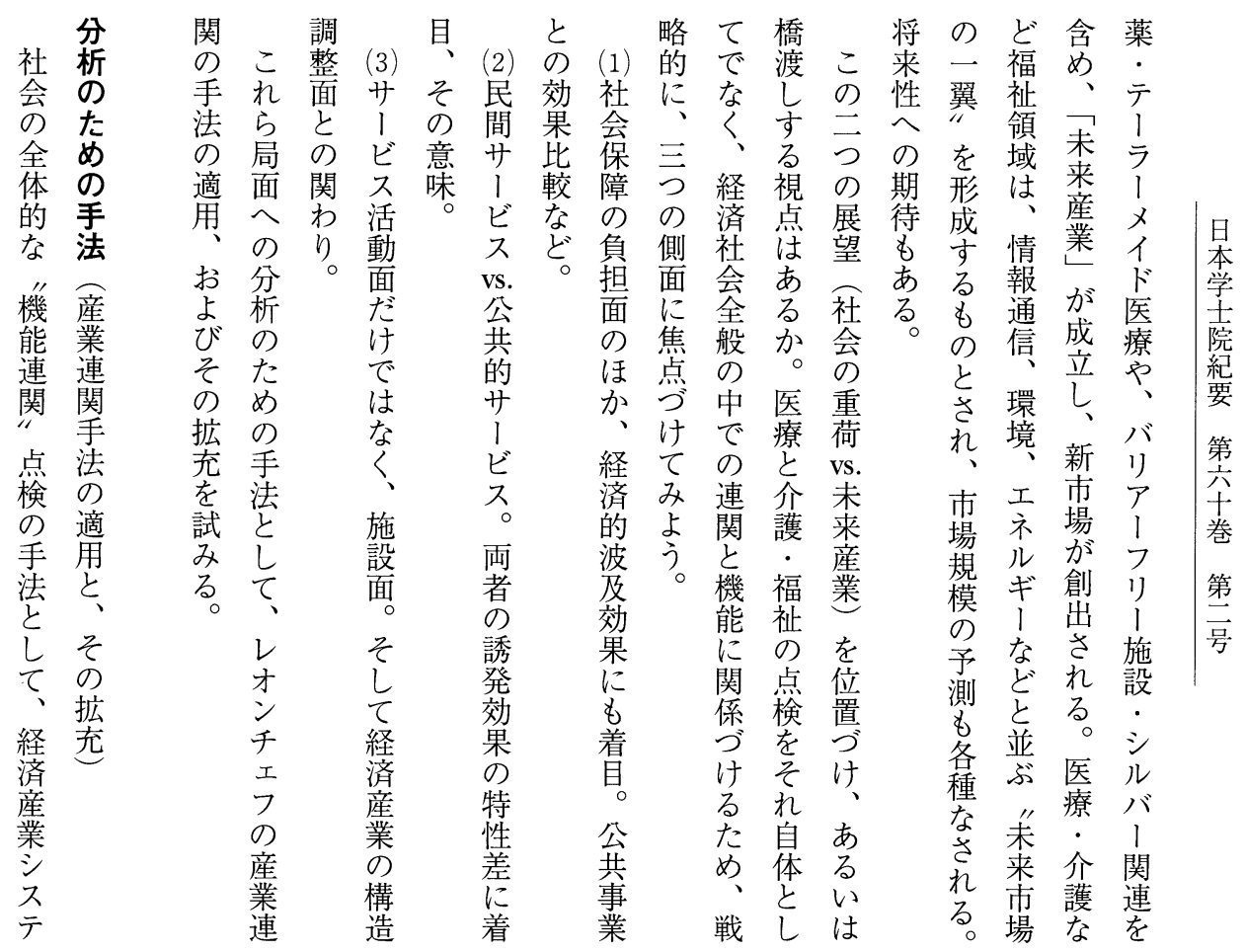

証性成 の家異相よ省 数、存へる互つ厚省の統ヨ重給組面、般 数て産パの他にて生庁作括コ結 バみをを多の

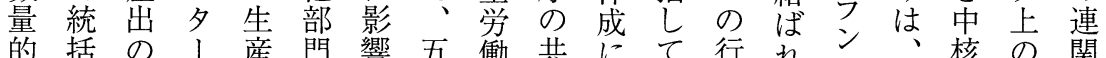
に的販ン物かし年省同は表列て杂学巷を

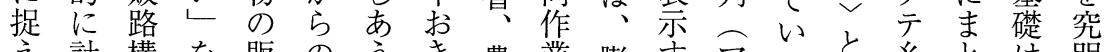
え計構を販のう農業膨守令ると系とは明

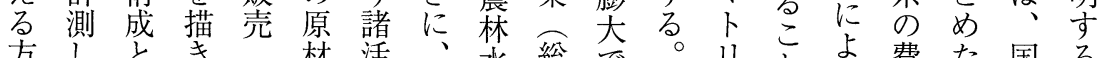

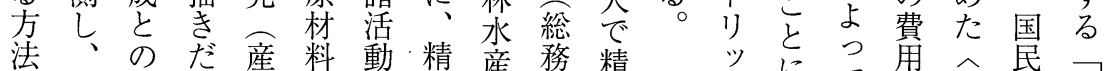
とか経す出学は莫省省力方着ての経経産

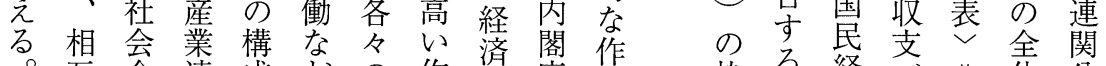
互全連成どの作産府業枠る。経バ $\mid$ 体分

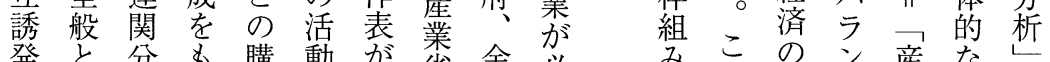

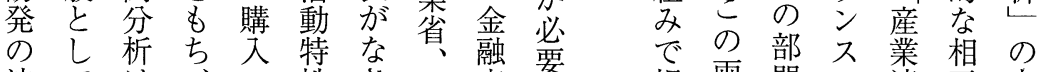
波ては、へ性さ国庁要捉両門々連相方

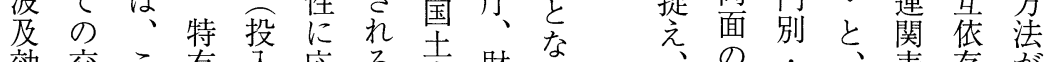
効交こ有入底る。紊財る

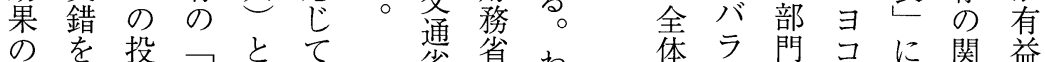
のを投投とて 省省わ体ラ間采を関益

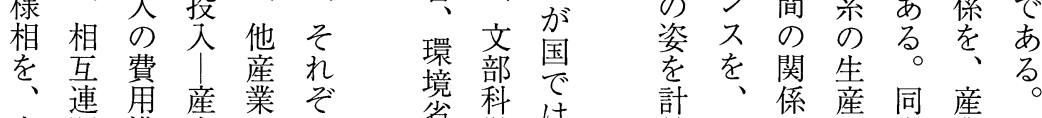

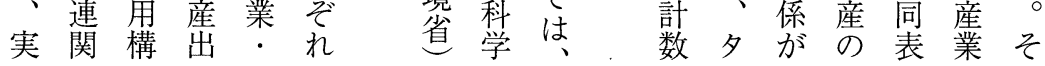




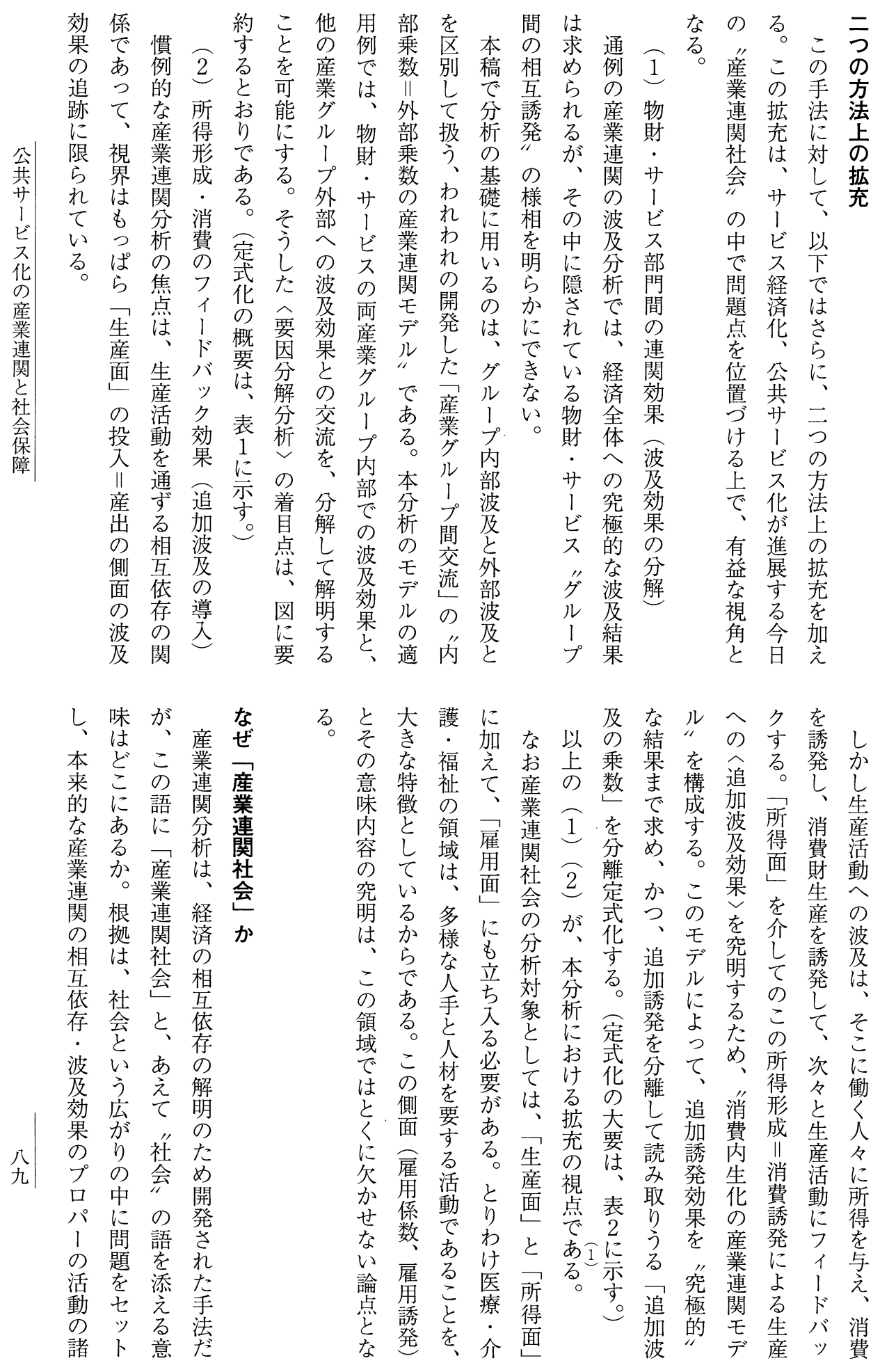




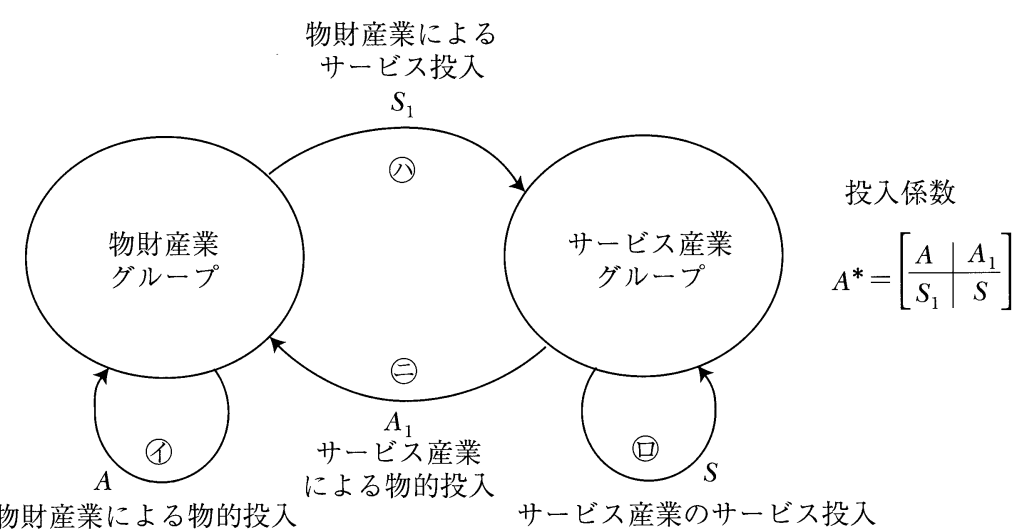

《逆行列係数の分解公式》（証明略）

$$
B^{*}=\left(I-A^{*}\right)^{-1}=\left[\begin{array}{c|c}
B+B_{2} M B_{1} & B_{2} M \\
\hline M B_{1} & M
\end{array}\right]=\left[\begin{array}{c|c}
N & N T_{1} \\
\hline T_{2} N & T+T_{2} N T_{1}
\end{array}\right]
$$

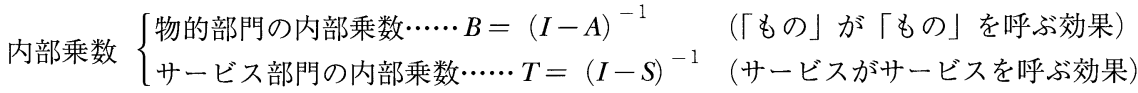

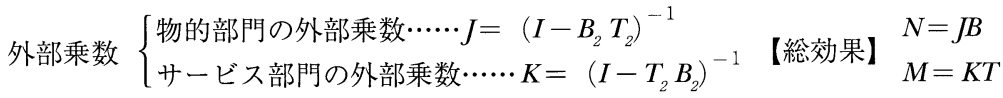
*4つの相互誘発倸数
$\left\{\begin{array}{l}\text { 投入誘発 } \\ \text { 内部生産誘発 }\end{array}\right.$
(1) $B_{1}=S_{1} B$
(3) $T_{1}=A_{1} T$
(2) $T_{2}=T S_{1}$
(4) $B_{2}=B A_{1}$

**各グループ内の総効果の分解

(「積」抢よび「和」の形)

$$
\left\{\begin{array}{l}
N=J B=B+B_{2} M B_{1} \\
M=K T=T+T_{2} N T_{1}
\end{array}\right.
$$

1.モデルの提示と計測は、宮澤健一（1963）『経済機構の連関分析』東洋経済新報社、およ びK. Miyazawa (1976), Input-Output Analysis and the Structure of Income Distribution, Berlin \& New York, Springer-Verlag.

2. われわれの内部乗数 - 外部乗数の相互連関モデル、および所得連関モデルを適用し、欧 米・アジア・日本の地域分析その他に応用した研究報告と方法論解明の論文集成は、G. J. D. Hewings, M. Sonis, M. Madden and Y. Kimura eds. (1999), Understanding and Interpreting Economic Structure, Berlin, Springer-Verlag.

3. 医療・福祉など、社会保障領域へのわれわれの応用分析については、別掲。

本分析の基礎デー夕は、総務省など 10 省庁共同編集（2004）『平成 12 年（2000年）産業連関 表』の基本分類表 $(517 \times 405)$ をベースとして、これを再編成・作成した統合 56 部門表「公 共経済と医療・介護・福祉分析用の産業連関表」による。 
表 1 物財・サービス交流の産業連関効果（波及効果の分解）

経済全般への波及の究極結果を示す係数（逆行列係数）の、要因分解。図を参照。

要因分解された諸係数は、大別して（i）各産業グループ “内”、(ii) 産業グループ“間”の、 2群の係数から構成され、(iii) の定式で連結される。

(i) グループ内の内部波及・外部波及

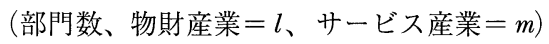

(1)図の (1)の波及ルート: 物的部門内部乗数 $B=(I-A)^{-1}$

ある物財の生産のためには他の物財が必要になるという、「もの」が「もの」を呼ぶ誘発効 果。物的産業グループ内部での生産波及効果。 $(l \times l)$

(2)(1-(1)- $\Theta-(1)$ 波及ルート: 物的部門外部乗数 $J=\left(I-B_{2} T_{2}\right)^{-1}$

物財の生産のためにはサービスの投入が必要で、そのサービスの投入がサービスの内部生 産を誘発し、それが物的内部生産へと波及するフィードバック効果。 $(l \times l)$

* [ 物的部門総効果 $] \quad N=J B \quad$ (和の形への変形、後出)

(3)図の(1)の波及ルート: サービス部門内部乗数 $T=(I-S)^{-1}$

あるサービス生産のために他のサービスが必要になるという、サービスがサービスを呼ぶ 誘発効果。サービス産業グループ内部での波及効果。 $(m \times m)$

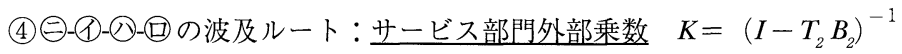

サービス生産のためには物財の投入が必要で、その物財投入が物的産業の内部生産を誘発

し、それがサービス内部生産へと波及するフィードバック効果。 $(m \times m)$

* [サービス部門総効果 $] \quad M=K T \quad$ (和の形への変形、後出)

(ii) グループ間の相互誘発係数（投入誘発、内部生産誘発）

(1)物的部門内部生産波及の “サービス投入誘発係数” $B_{1}=S_{1} B$

物的部門の内部生産波及によって、サービス投入が誘発される効果。 $(m \times l)$

(2)物的部門サービス投入の “サービス内部生産誘発係数” $T_{2}=T S_{1}$

物的部門のサービス投入によって、サービス部門の内部生産が誘発される効果。 $(m \times l)$

(3)サービス部門内部生産波及の “物的投入誘発係数” $T_{1}=A_{1} T$

サービス部門の内部生産波及によって、物的投入が誘発される効果。 $(l \times m)$

(4)サービス部門物財投入の “物的内部生産誘発係数” $B_{2}=B A_{1}$

サービス部門の物財投入によって、物的部門の内部生産が誘発される効果。 $(l \times m)$

（iii） 究極効果の要因分解（逆行列係数の分解公式）

産業連関全般の波及の究極結果を示す係数表は、上記の内部乗数・外部乗数と産業グルー プ間の相互誘発係数の「積」または「和」の形で表される。(証明略)

九

$$
B^{*}=\left(I-A^{*}\right)^{-1}=\left[\begin{array}{c|c}
B+B_{2} M B_{1} & B_{2} M \\
\hline M B_{1} & M
\end{array}\right]=\left[\begin{array}{c|c}
N & N T_{1} \\
\hline T_{2} N & T+T_{2} N T_{1}
\end{array}\right]
$$

*定式化の詳細、および応用例は、注（1）の文献を参照。 
慣例的な産業連関のレオンチェフ・ルートは、生産活動を通ずる相互依存の関係にあり視 界はもっぱら「生産面」の波及効果の追跡に限られる。しかし、生産への波及は、同時に、 所得の形成と消費の誘発を通じ、生産面へ追加波及を誘発する。

そうした「所得面」でのケインズ・ルートの追跡を、マクロではなく部門別に、所得面で はなく生産面で捉える。その総効果は、下記(1)に(2)を連結して、(3)の形で求められる。

(1)産業連関の生産誘発：[レオンチェフ・ルート]

(生産活動の相互依存を通ずる、生産面での波及効果)

本来のくレオンチェフ逆行列乗数 $>B^{*}=\left(I-A^{*}\right)^{-1}$

(2)近得形成と消費誘発：[ケインズ・ルート多部門化］

（生産への波及の結果、所得が生まれ、消費支出を呼ぶ）

$v=$ 部門別付加価值率 (行ベクトル) $\Rightarrow$ 部門別の所得形成 $=v B^{*}$

$c=$ 品目別消費係数（列ベクトル） $\Rightarrow$ 品目別の消費誘発 $=c v B^{*}$

(3)逍費内生化の産業連関：［レオンチェフ＝ケインズ結合モデル］

（所得が形成され、消費がなされて、生産への誘発が追加される）

最終需要を $\left[\begin{array}{l}\text { 内生的な消費需要 }=f^{c}=c v X \\ \text { 外生的な最終需要 }=f\end{array}\right]$

に分離

そのとき、

*需給バランス式

$$
\begin{aligned}
{\left[I-A^{*}\right] \quad X } & =f+f^{c} \\
{\left[I-A^{*}-c v\right] \quad X } & =f \\
X & =\left[I-A^{*}-c v\right]^{-1} f
\end{aligned}
$$

$<$ 解 $>=$ 拡大逆行列表示

$$
\begin{aligned}
\text { 拡大逆行列係数の分解 } & {\left[I-A^{*}-c v\right]^{-1} } \\
& =\left[B^{*-1}-c v\right]^{-1}=\left[\left(I-c v B^{*}\right) B^{*-1}\right]^{-1} \\
& =B^{*}\left(I-c v B^{*}\right)^{-1}
\end{aligned}
$$

<拡大逆行列乗数 $>=$ < レオンチェフ逆行列乗数 $>\times<$ 追加波及の乗数 $>$

この<追加効果の分離定式化>の公式によって、

1. 生産波及の全拡大効果から、“追加誘発効果”（=追加波及の乗数）の部分を分離して計測

し、評価することができるようになる。

2. 係数 $v, c$ は、ベクトルではなく、所得階層別マトリックスとしても、規定できる。この 「部門別・所得層別の付加価値率」「品目別・所得層別の消費係数」の導入によって、

産業連関に対応するく近得連関 $>$ 構造が、

多部門型所得層別 “所得分配” の与える効果の形において、究明可能となる。

*定式化の詳細、および応用例は、注（1）の文献を参照。 


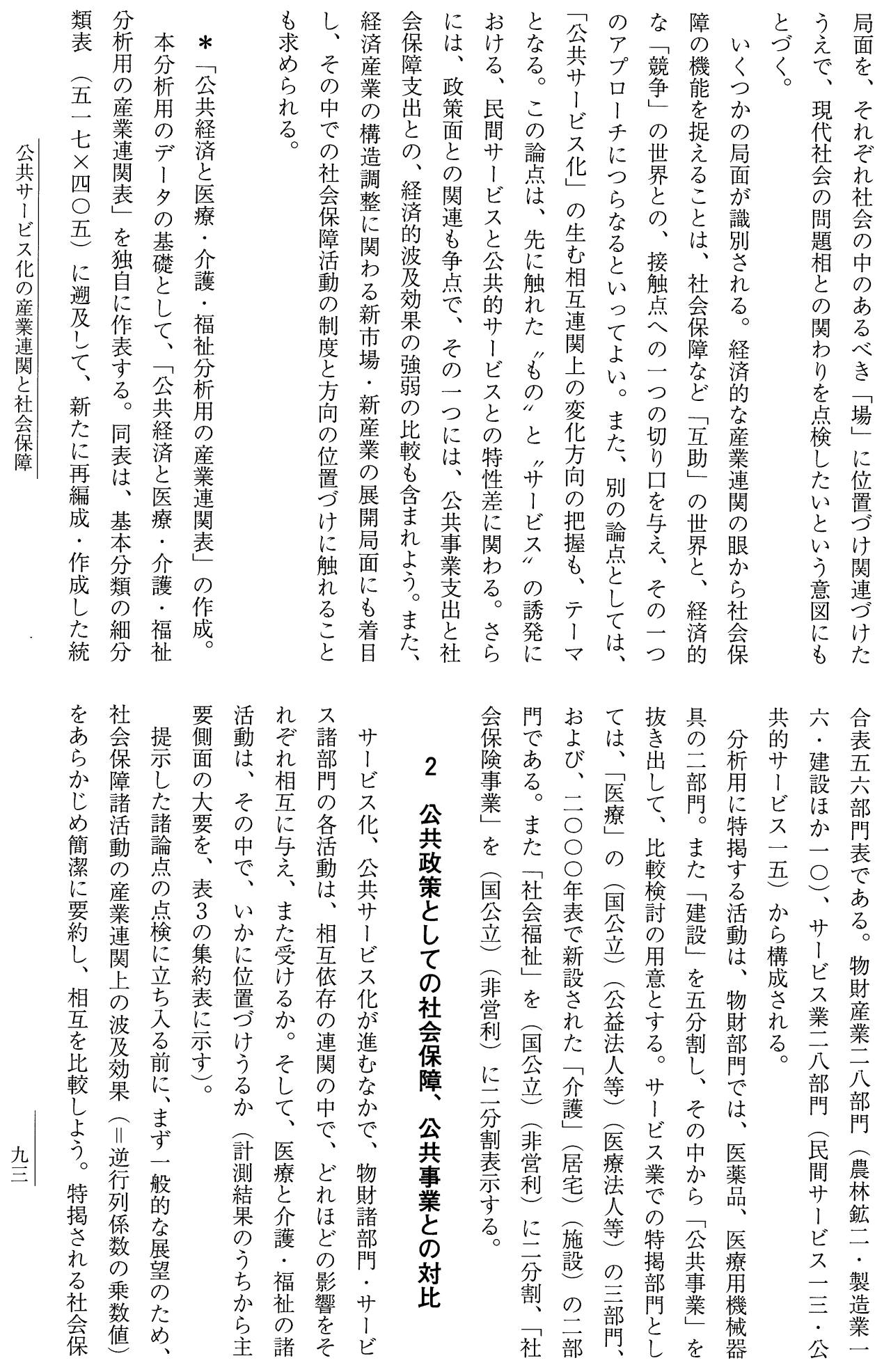


表 3 産業連関効果の主要係数（抄）：要約 - 2000 年 56 部門一

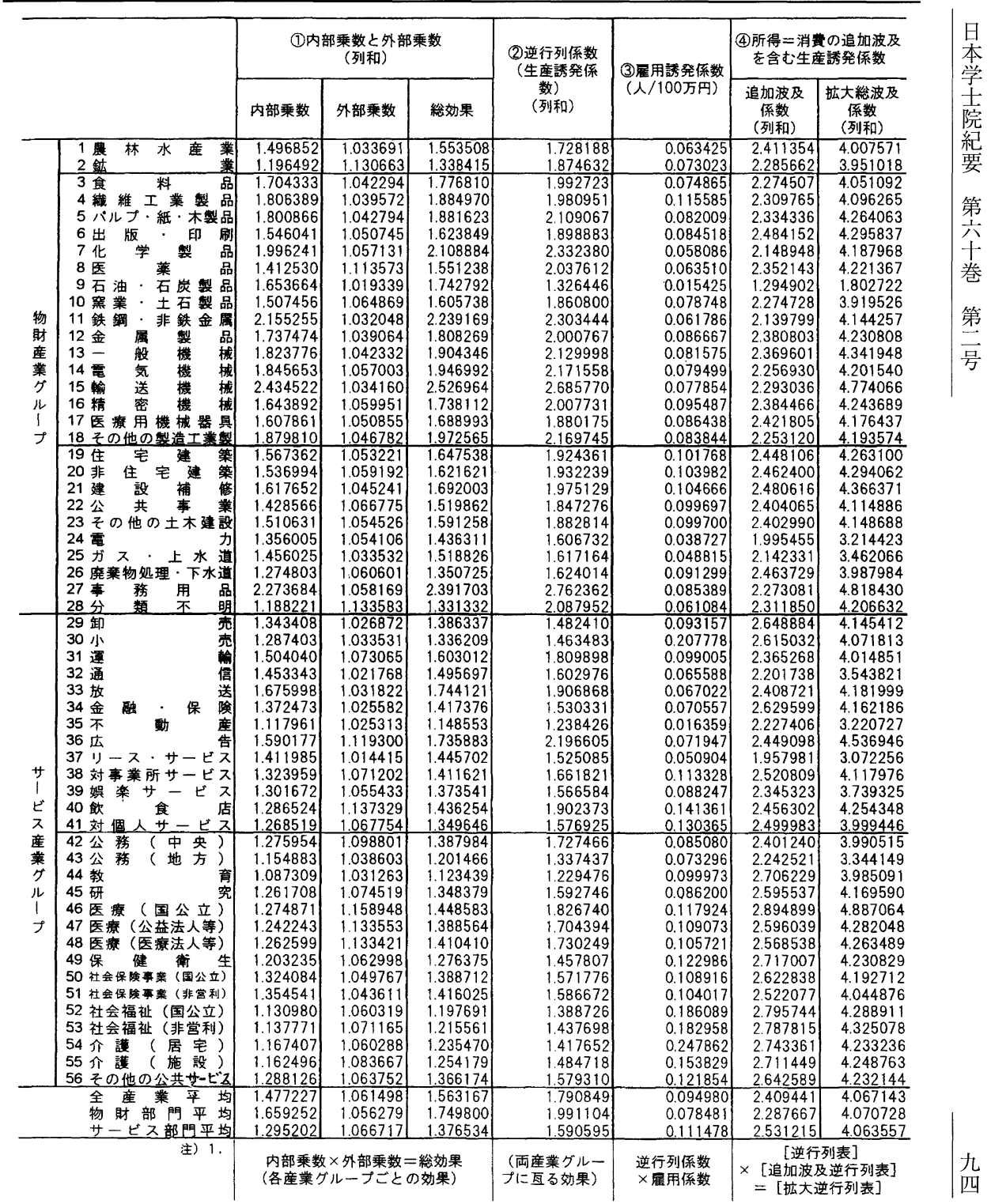

2.「(4)所得二消費の追加波及を含屯生産誘発係数は、（家計現実消費／純所得ベース）である。 
付表 医療福祉諸部門の生産誘発係数 一波及先比較一

\begin{tabular}{|c|c|c|c|c|c|c|c|c|c|}
\hline & \multicolumn{3}{|c|}{ 医 } & \multicolumn{2}{|l|}{ 介 } & \multicolumn{2}{|c|}{ 社会福祉 } & \multicolumn{2}{|c|}{ 社会保険事業 } \\
\hline & (国公立) & (公益法人等) & (医療法人等) & (居 宅) & (施 設) & (国公立) & (非営利) & (国公立) & (非営利) \\
\hline 01 農 林 水 産 業 & 0.007550 & 0.006435 & 0.007099 & 0.012898 & 0.017605 & 0.018249 & 0.018777 & 0.001439 & 0.000802 \\
\hline 02 鉱 & 0.001412 & 0.001135 & 0.001088 & 0.001024 & 0.000935 & 0.000795 & 0.000873 & 0.001041 & 0.000976 \\
\hline 03 食 & 0.014242 & 0.011543 & 0.013114 & 0.026334 & 0.035918 & 0.035887 & 0.037192 & 0.000266 & 0.000193 \\
\hline 04 繊維工業製品 & 0.003941 & 0.002970 & 0.003488 & 0.003855 & 0.004287 & 0.004248 & 0.005943 & 0.005095 & 04633 \\
\hline 05 パルプ・紙・木製品 & 0.017208 & 0.013389 & 0.015758 & 0.018684 & 0.017829 & 0.020298 & 0.024829 & 0.033257 & 0.016618 \\
\hline 06 出 版 - 印 刷 & 0.018159 & 0.014182 & 0.019121 & 0.007676 & 0.009070 & 0.020610 & 0.018093 & 0.043263 & 0.044268 \\
\hline 07 化 学 製 品 & 0.036105 & 0.027691 & 0.027237 & 0.012813 & 0.016218 & 0.011888 & 0.013972 & 0.006502 & 0.006160 \\
\hline 08 医 & 0.174041 & 0.155361 & 0.155756 & 0.017593 & 0.055052 & 0.009143 & 0.012842 & 0.000061 & 0.000063 \\
\hline 09 石油・石炭製品 & 0.012926 & 346 & 0.009776 & 0.008069 & 7928 & 0.006851 & 0.007148 & 0.005269 & 0.005101 \\
\hline 10 窯業・土石製品 & 0.0 & 40 & 419 & 0.004149 & 3971 & 0.003464 & 0.004500 & 0.001073 & 1158 \\
\hline 11 鉄鋼 - 非鉄 金属 & 0.008354 & 0.006222 & 0.006425 & 0.003613 & 1340 & 0.003850 & 0.004937 & 0.003577 & 3756 \\
\hline 12 金 & 0.007097 & 0.006118 & 0.005574 & 0.004280 & 5091 & 87 & 7262 & 3175 & 669 \\
\hline $13-$ & 0.003057 & 0.002519 & 0.002688 & 0.001846 & 0.001807 & 41 & 582 & 4321 & 08 \\
\hline 14 電 & 0.003462 & 0.002850 & 0.003001 & 0.001679 & 0.001896 & 0.001685 & 0.001695 & 3828 & 799 \\
\hline 15 輸 & 0.005049 & 0.004202 & 0.004531 & 0.002744 & 0.003001 & 0.002679 & 0.002455 & 0.006820 & 0.008645 \\
\hline 16 精 & 0.000246 & 0.000203 & 0.000213 & 0.000124 & 0.000147 & 0.000118 & 0.000137 & 0.000142 & 0.000153 \\
\hline 17 医療用機械器具 & 0.006633 & 0.005327 & 0.005451 & 0.001699 & 0.002459 & 0.002096 & 0.001549 & 0.000015 & 0.000019 \\
\hline 18 その他の製造工業製品 & 0.01 & 0.0 & 58 & 0.010805 & 9958 & 0.009842 & 0.012624 & 0.007779 & 0.008224 \\
\hline 19 住 & 0.000000 & 0.000000 & 00 & 0000 & 000 & 100 & 0000 & 0000 & 000 \\
\hline 20 非 住 宅 建 築 & 0.000000 & 0.000000 & 000 & 0.000000 & 000 & 00 & 000 & 0000 & 000 \\
\hline 21 建 & 0.013610 & 0.012189 & 7878 & 0.010316 & 1659 & 78 & 0.0 & 122 & 318 \\
\hline 22 公 & 0.000000 & 0.000000 & 0.000000 & 0.000000 & 0000 & 0.000000 & 0.000000 & 0000 & 000 \\
\hline 23 その他の土木建設 & 0.000000 & 0.000000 & 0.000000 & 0.000000 & 0.000000 & 0.000000 & 0.000000 & 0000 & 000 \\
\hline 24 電 & 0.025389 & 0.023635 & 3862 & 0.023574 & 3585 & 0.014497 & 0.017168 & 0.043647 & 0.039697 \\
\hline 25 ガ オ & 0.0 & 105 & 276 & 0.014660 & 2789 & 0.011575 & 0.012186 & 0.011376 & 0.011062 \\
\hline 26 廃棄物処 & & 202 & & 069 & 860 & 0.003043 & 0.004089 & 5997 & 836 \\
\hline 27 事 & 0.0 & & & 384 & & & 0. & 443 & 83 \\
\hline 28 分 & 0.0 & 0.0 & & 14 & & & 80 & 4711 & 82 \\
\hline 29 卸 & 91 & 0.0 & 31 & 80 & 303 & & 940 & 071 & \\
\hline 30 小 & 727 & 90 & 147 & 3794 & 32 & & 90 & 492 & 24 \\
\hline 31 運 & 0.042895 & 649 & 410 & 0.029624 & 271 & 27 & 689 & 24 & \\
\hline 32 通 & 0.018328 & 791 & 975 & 0.008062 & 0355 & 0.006787 & 42 & 1275 & 371 \\
\hline 33 放 & 0.003973 & 508 & 107 & 0.001601 & 2221 & 01203 & 1346 & 2705 & 747 \\
\hline 34 金 & 59 & 912 & 283 & 0.025944 & 189 & 0.020250 & 0.022533 & 4725 & 0. \\
\hline 35 & 95 & & 43 & 802 & 22 & 65 & 913 & 3827 & 545 \\
\hline 36 広 & & & & 53 & 71 & 11 & 462 & 265 & 340 \\
\hline 37 リース・サービス & & & & 89 & 99 & & 26 & 304 & 69 \\
\hline 38 対事業所サービス & 79 & & & & & & & 299 & 74 \\
\hline 39 娛楽サービス & 0.002240 & 394 & 126 & 0.00 & 233 & 32 & 85 & 16 & \\
\hline 40 飲 & 0.000000 & .000000 & 000 & 0.000000 & 000 & 00 & 000 & 000 & \\
\hline 41 対個 & 0.03 & 257 & 978 & 0.014241 & 2401 & 0.010943 & 6593 & 0923 & 22 \\
\hline 42 公務 & 0.00 & 90 & 299 & 0.000153 & 0181 & 0.000173 & 0.000152 & 0248 & 315 \\
\hline 地 方 & 0. & 77 & 56 & 0337 & 399 & 81 & 333 & 0545 & 692 \\
\hline 44 & & & & 165 & 43 & 36 & 53 & 829 & 349 \\
\hline 45 矿 & & & & 0. & 0. & 2 & 37 & 97 & 0.0 \\
\hline 国公立) & & & & & & & & 100 & 0.0 \\
\hline 47 医療 (公益法人等) & & & & 00 & 00 & & 000 & 00 & 000 \\
\hline 48 医療 (医療法人等) & & & & 0.000735 & 894 & & 00 & 00 & 000 \\
\hline 49 保 & 0.006324 & & & 0917 & 878 & 04 & 04 & 21 & 21 \\
\hline 50 社会保険事業(国公立) & 0.000000 & 000000 & & 0.000000 & 2000 & 000 & 000 & 000 & 00 \\
\hline 51 社会保険事業 (非営利) & 0.000000 & .000000 & 1000 & 0.000000 & 0000 & 0.000000 & 0.000000 & 0000 & 000 \\
\hline （国公立） & 0.000000 & 0.000000 & 000 & 0.000000 & 000 & 1.000000 & 0.000000 & 0000 & 000 \\
\hline 53 & 0.000000 & 0.000000 & .000000 & 0.000000 & 0.000000 & 0.000000 & 1.000000 & 0.000000 & 0.000000 \\
\hline 居 宅） & & & & 1.000000 & 0.000000 & 0.000000 & 0.000000 & 0.000000 & 0.000000 \\
\hline 施 設 ） & 0.000000 & 0.000000 & 0.000000 & 0.000000 & 1.000000 & 0.000000 & 0.000000 & 0.000000 & 0.000000 \\
\hline 56 その他の公共サービス & 0.001406 & 0.002956 & 0.002811 & 0.000707 & 0.001327 & 0.000527 & 0.000597 & 0.000891 & 0.001022 \\
\hline 計 & 1.826740 & 1.704394 & 1.730249 & 1.417652 & 1.484718 & 1.388726 & 1.437698 & 1.571776 & 1.586672 \\
\hline
\end{tabular}

注）上表のうち、「医療（国公立）」の生産誘発係数の值は、デー夕扱い上の制約から、過大に示されている点に留意された い。注 (4) を参照のこと。 


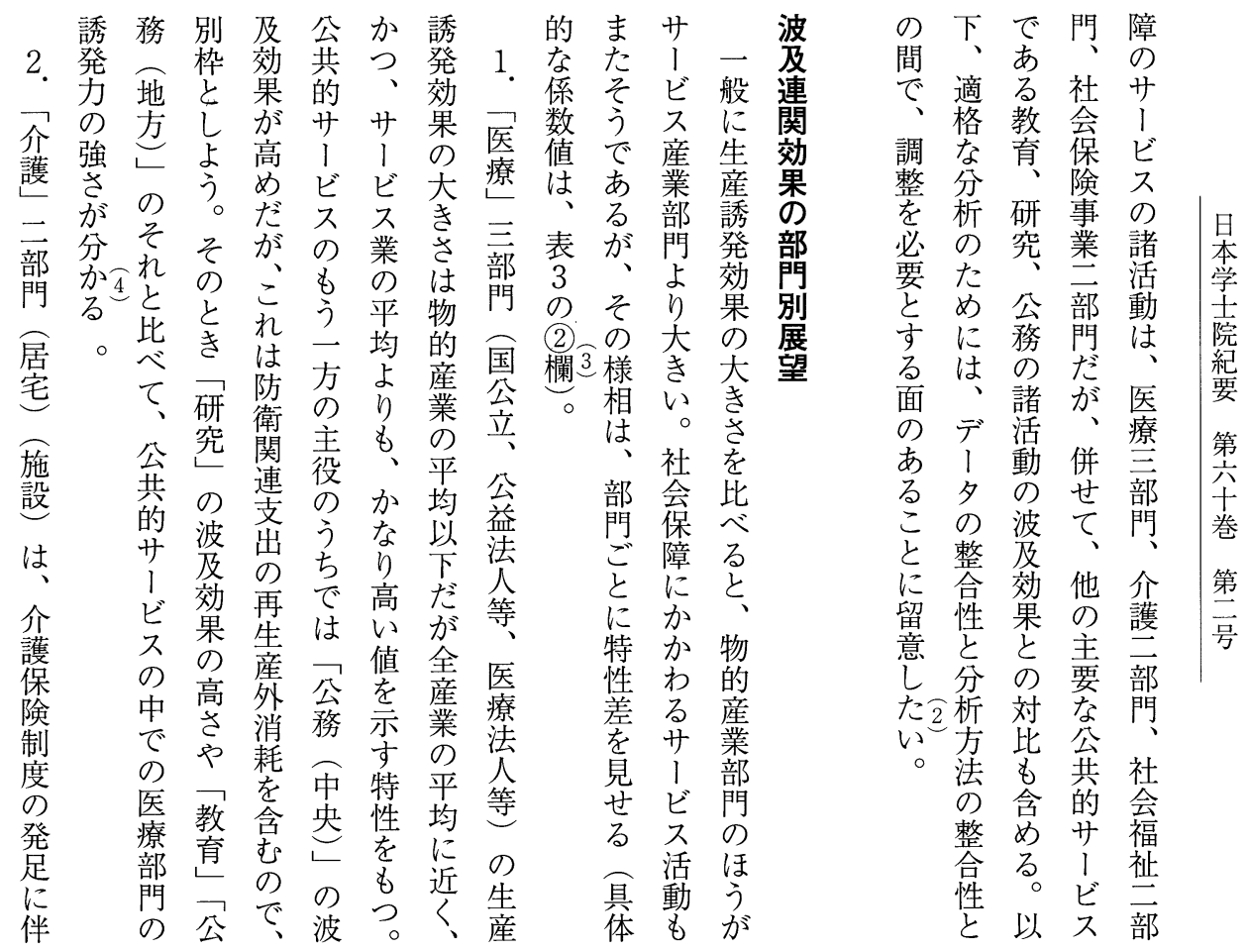

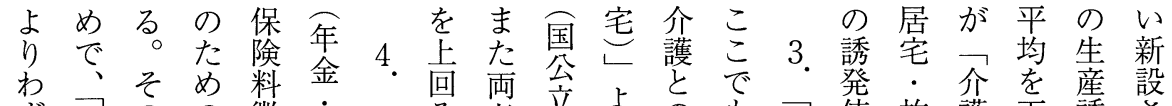

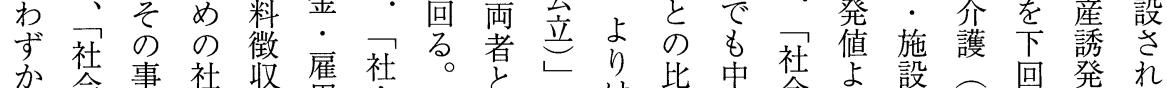

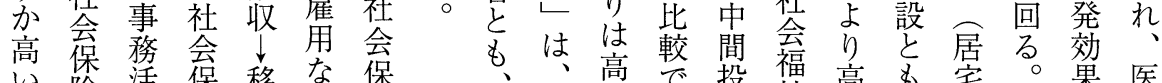
い険活保移な保、、高で投福高も宅。倮医

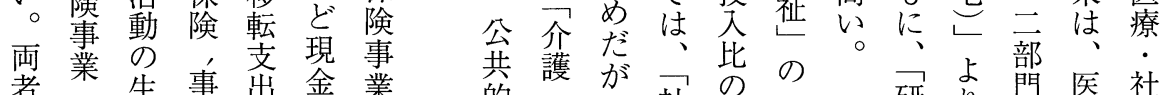

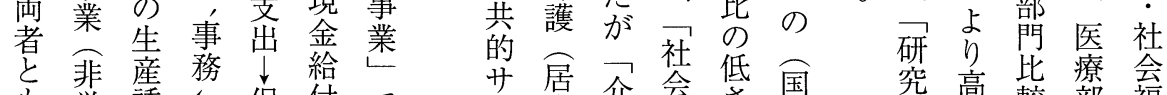

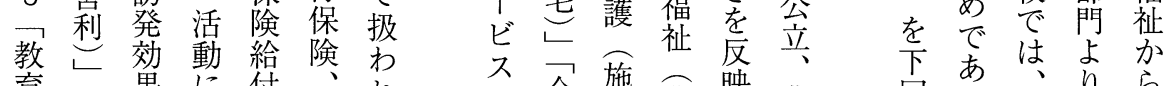
育の果に付、れ分施韭映非回あはよか

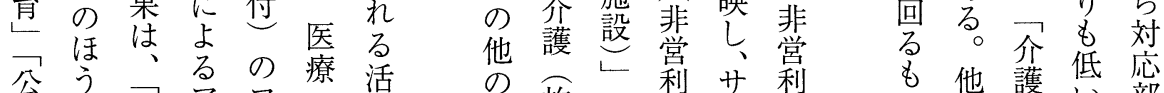
公務方社予 フ

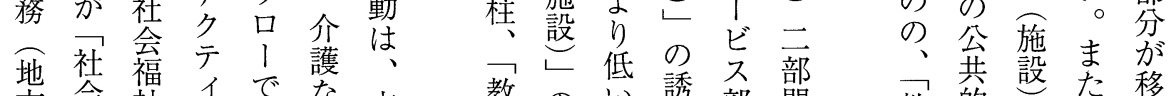

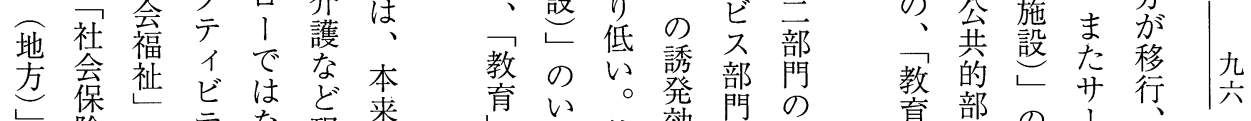

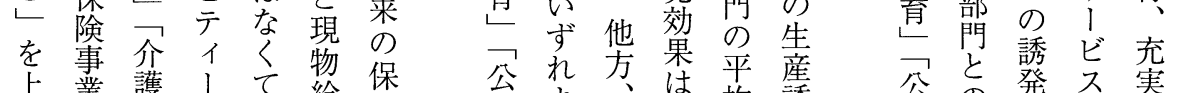

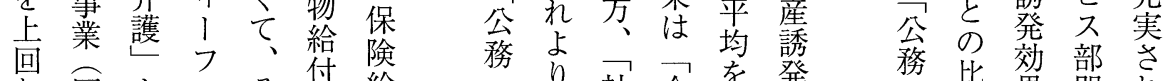

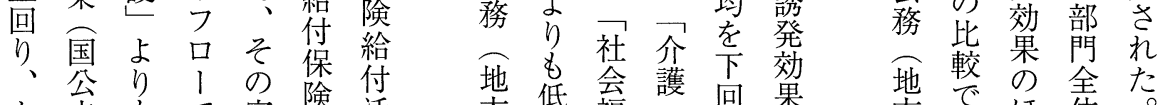

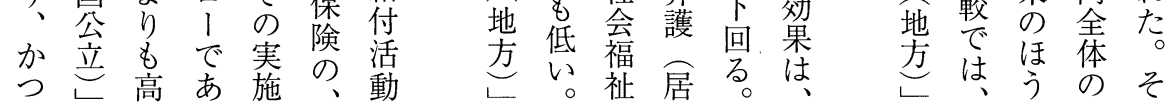



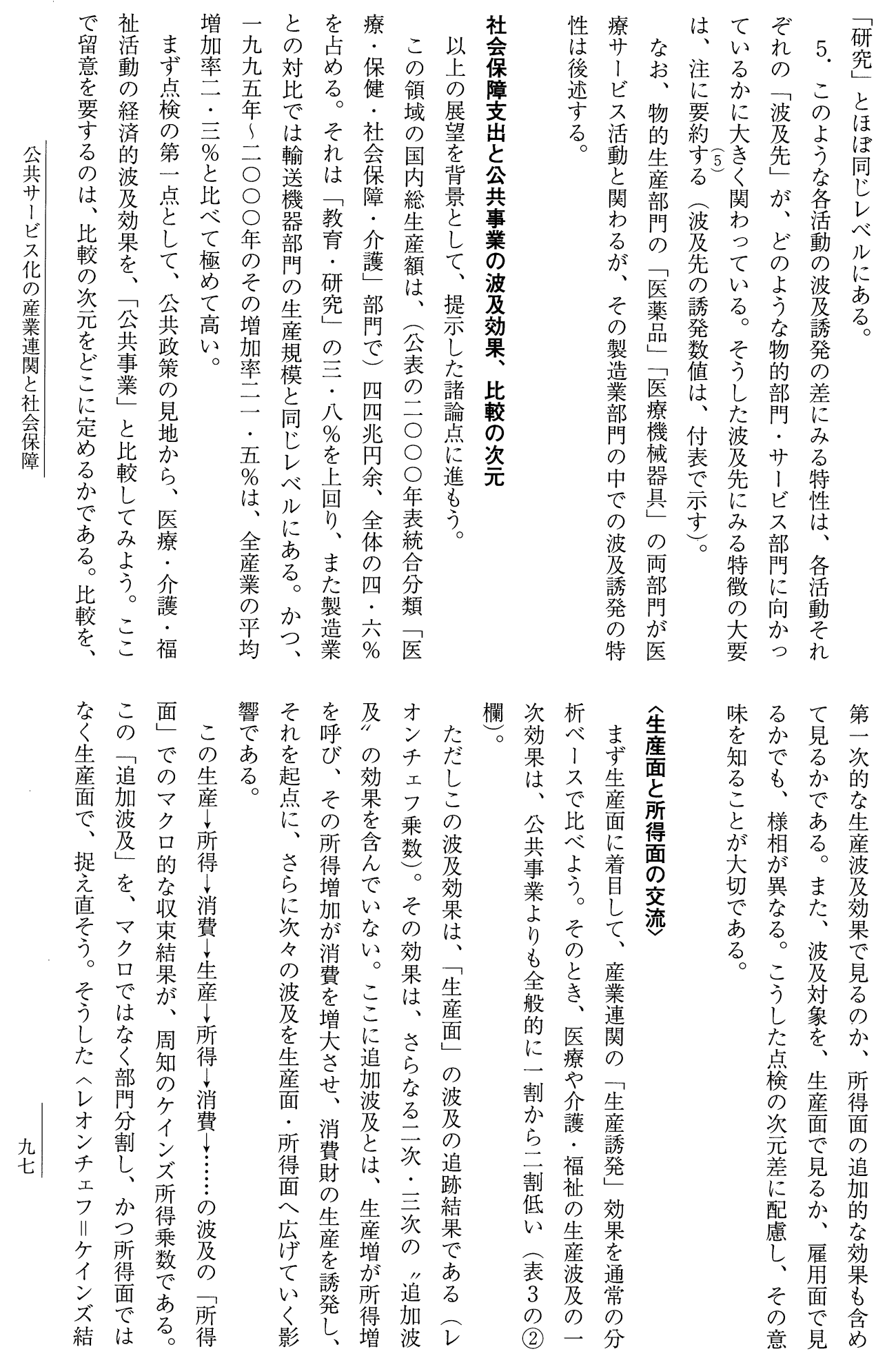

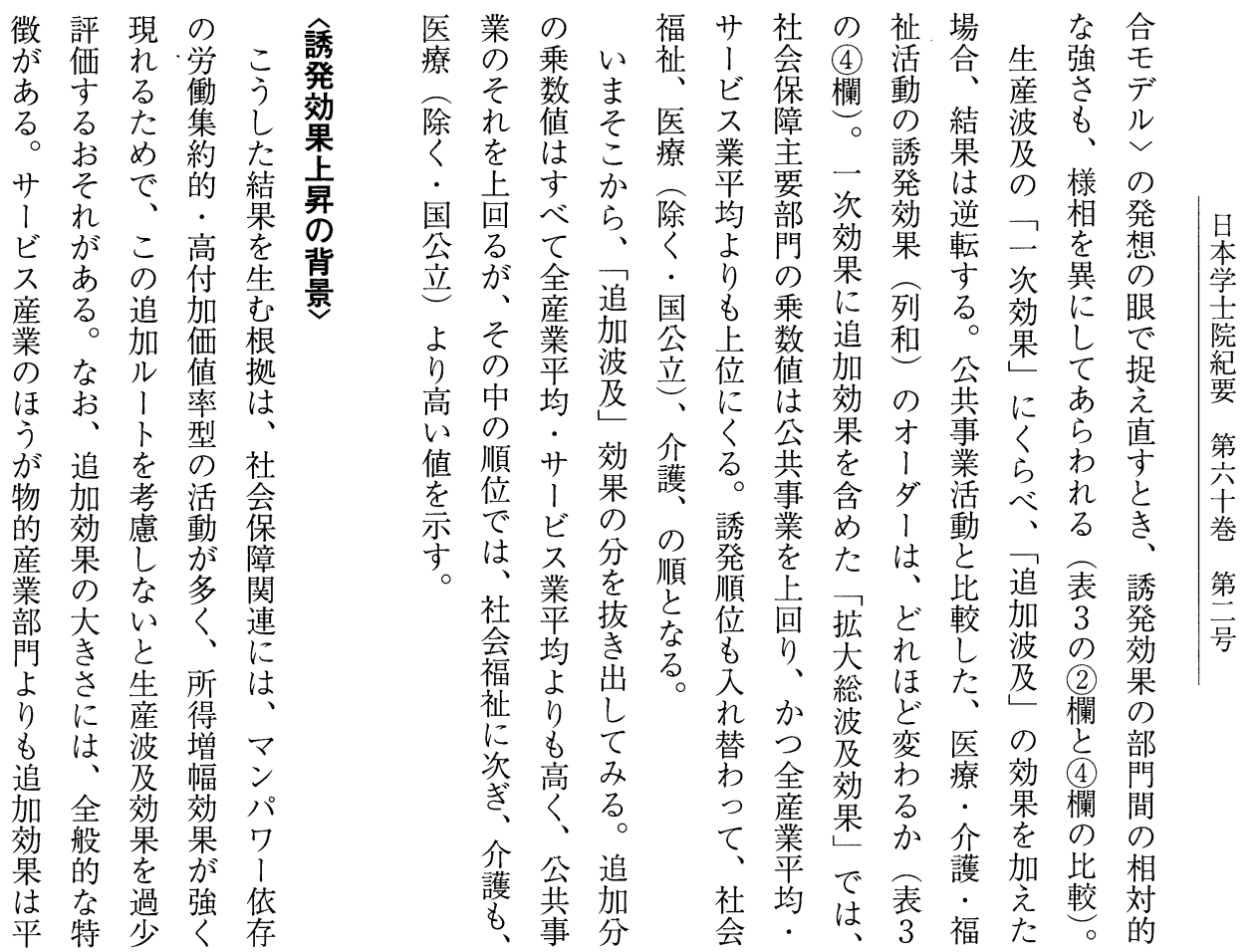

はか別所を圣る益数得は、要にら概占果社追平均 産でど分うと消負で消生念あ応対高保加均に 産あの配一集費担あ費産上点る比め障儿的高

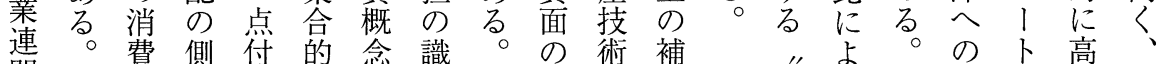
関た性面言支怘別後波を足供つたウをいか た向か守出三著及素給てた加。つ

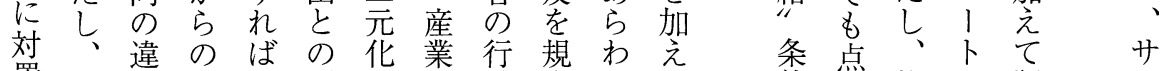

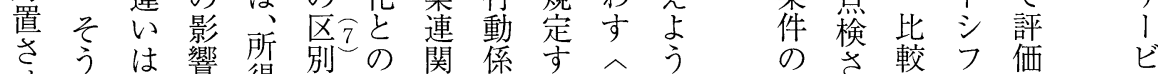

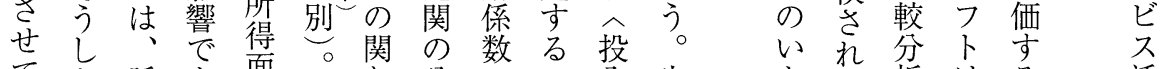

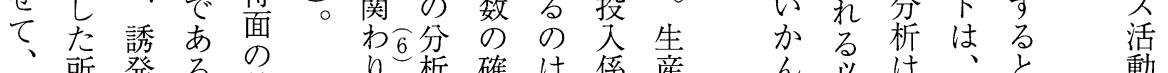

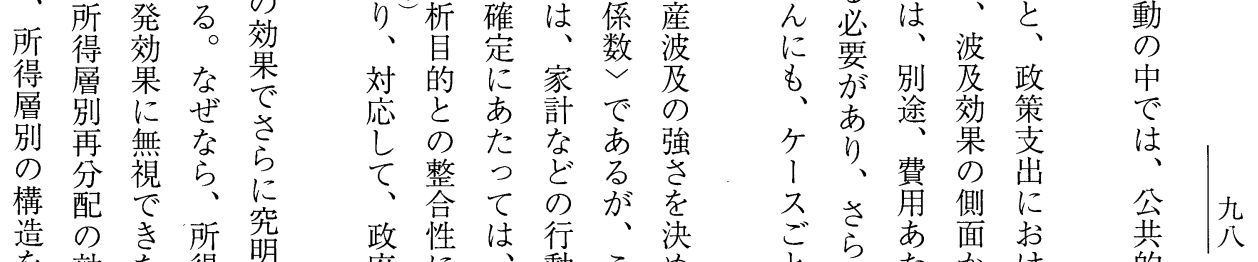

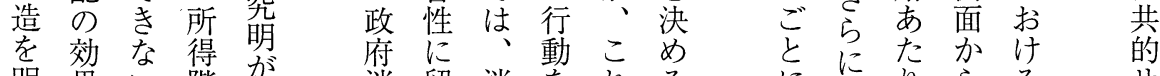
明果い階が消留消をれるるにうらる 示を影層望費意費示に対と注需美判公知

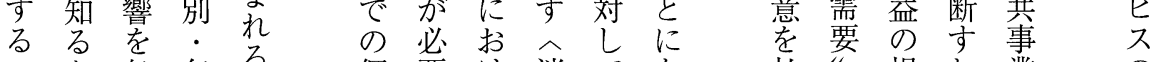

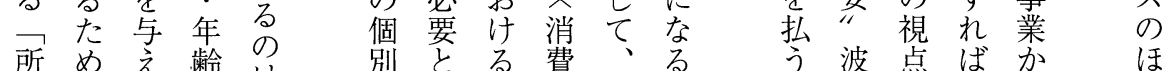
得にる層は、的な受係所の必度效占方 


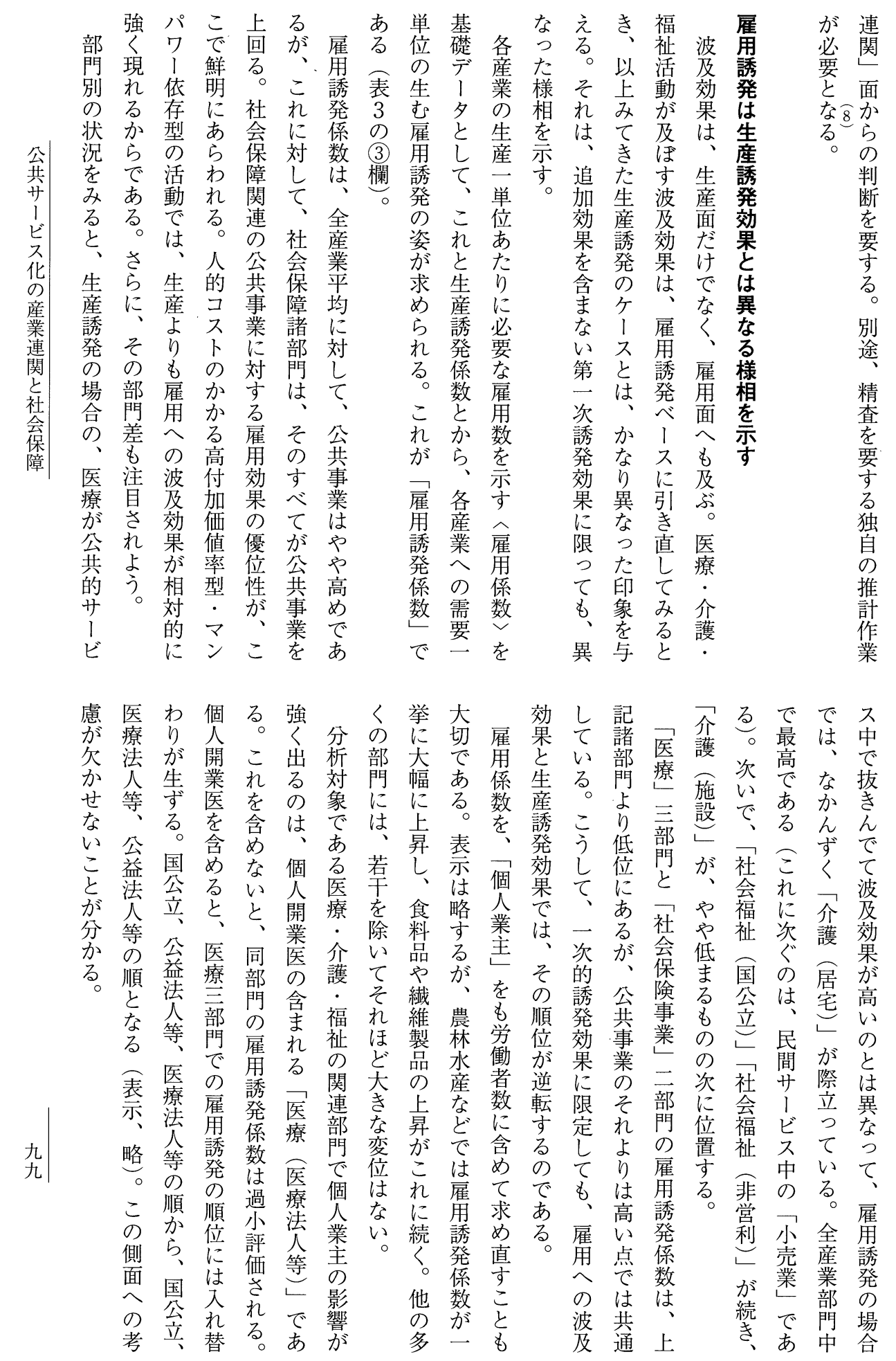




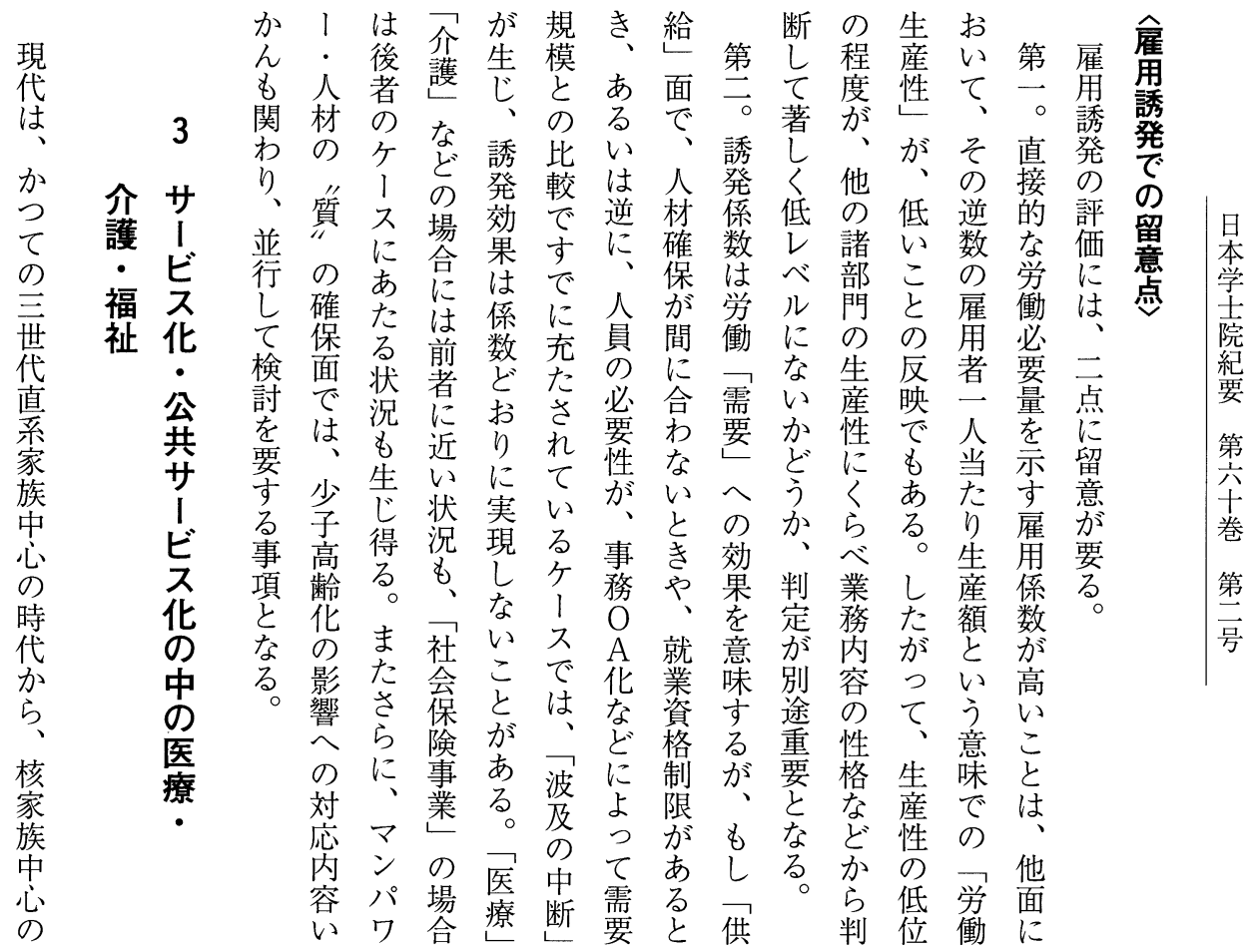

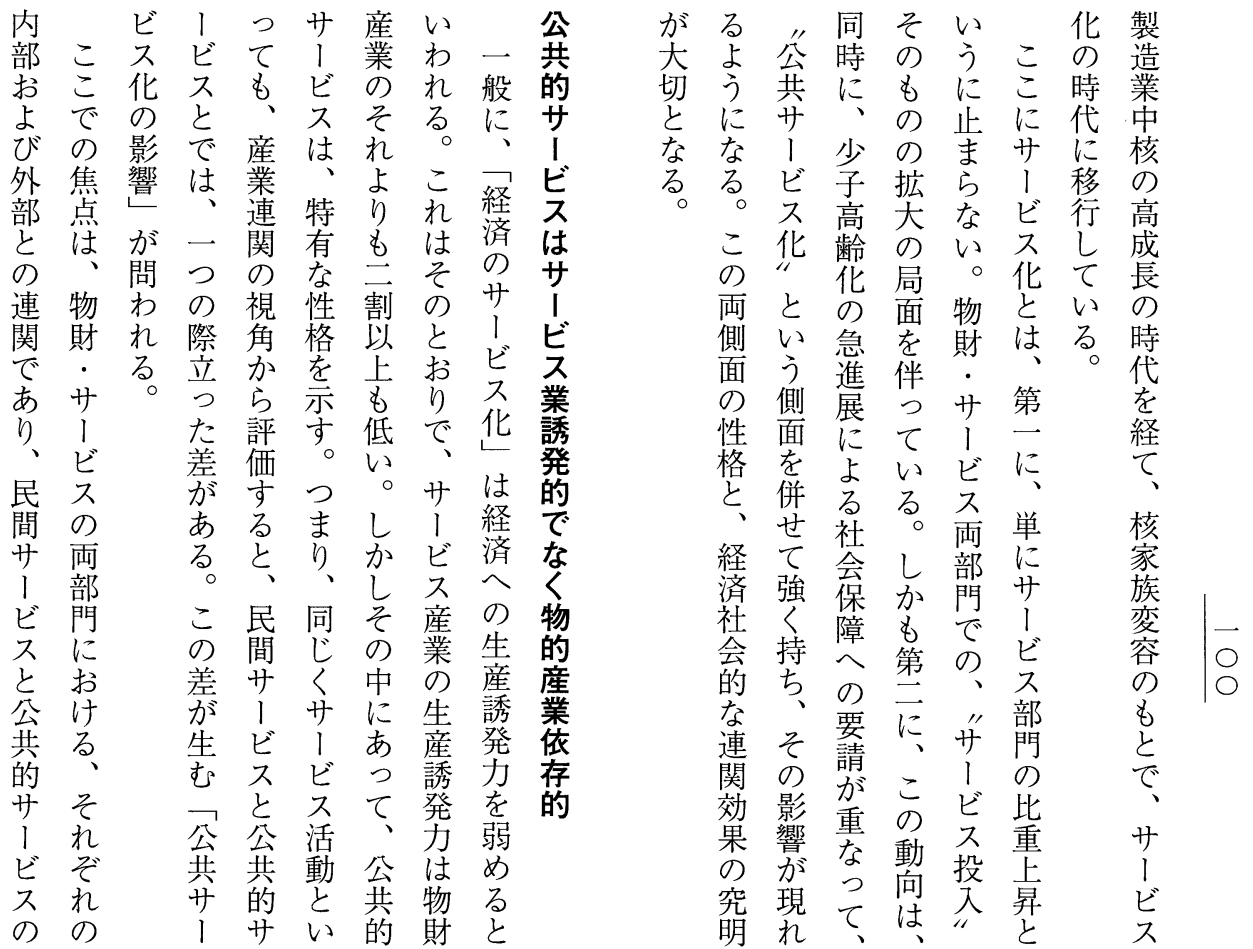


及れ筇にビ示

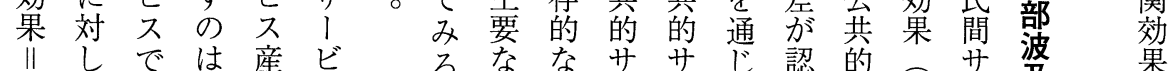

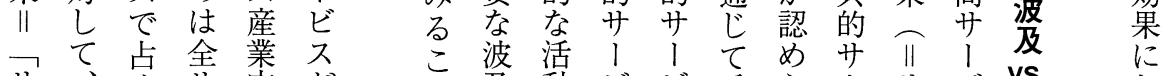

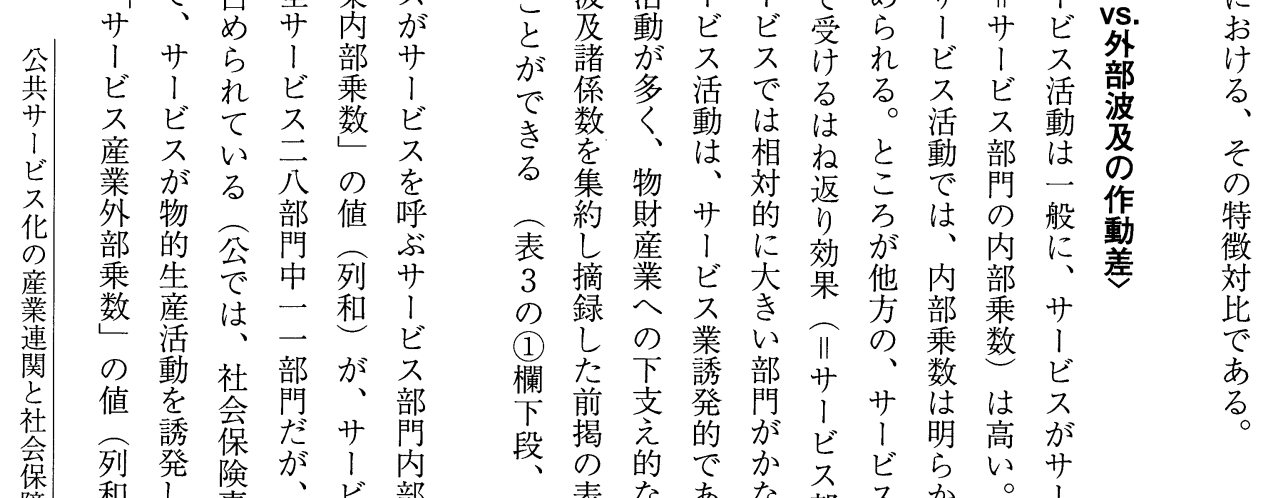

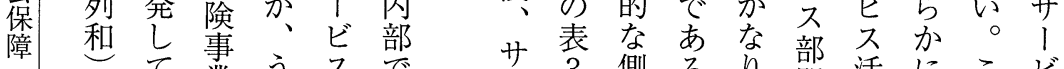

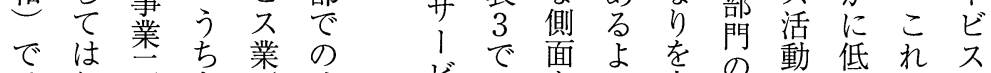
はね部九平波ビで面るを占の動低れ

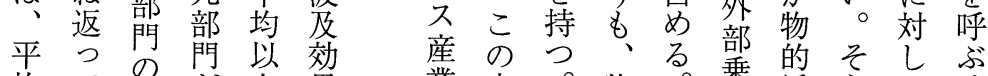

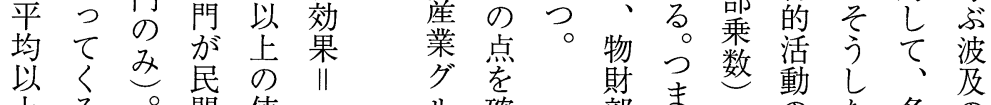

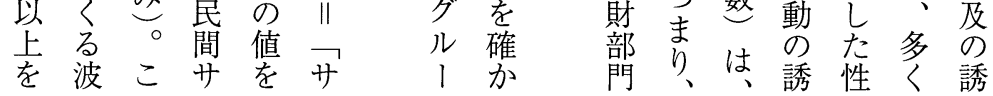

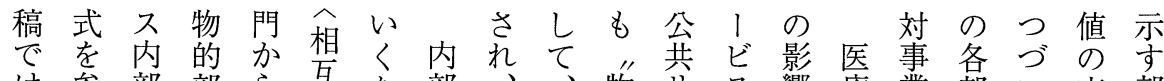
は参部部ら互た部、、物弄久響療業部い高部

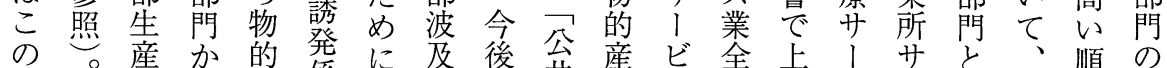

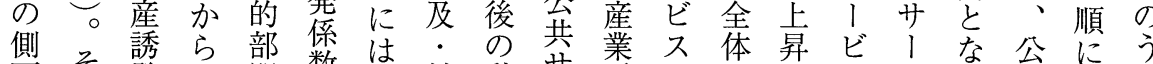

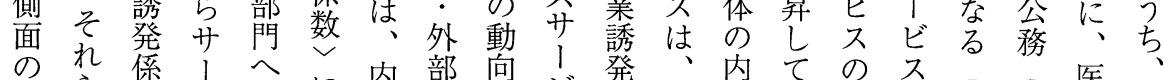
一 数 ビ の に内部向

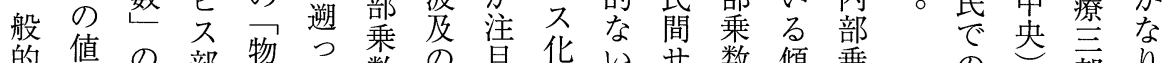

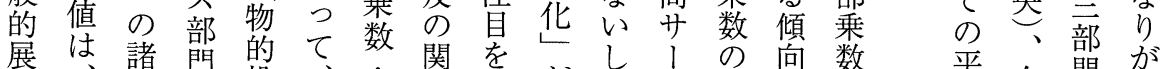
望々係へ投安連引が依ビ平向数平介門が

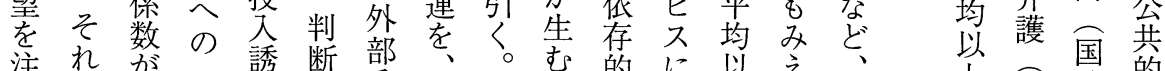

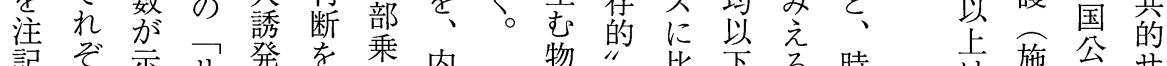

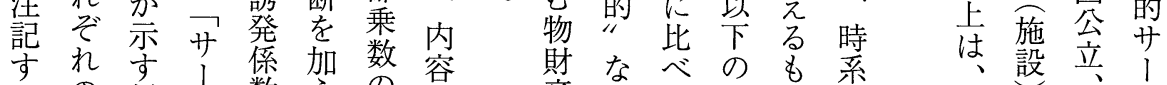

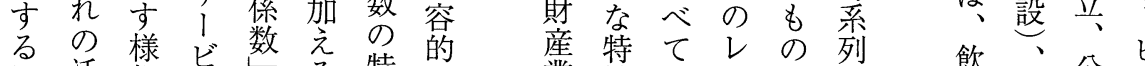
ほ活相スこる特に業性”べの的食研公 ビ ○| 㔔憅

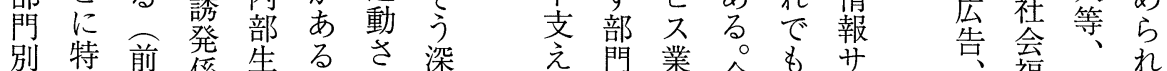

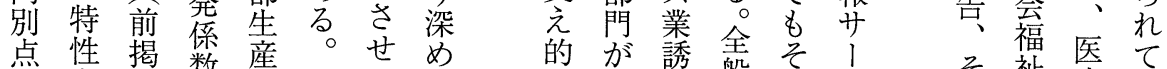

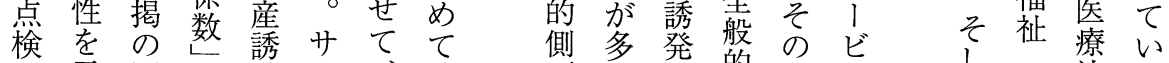

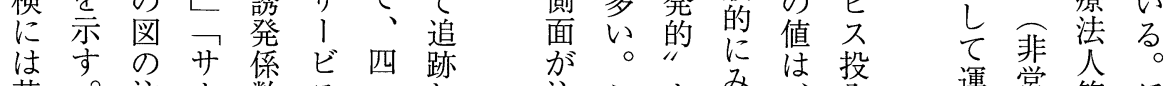
若。注 1 数

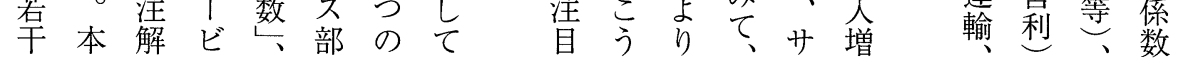




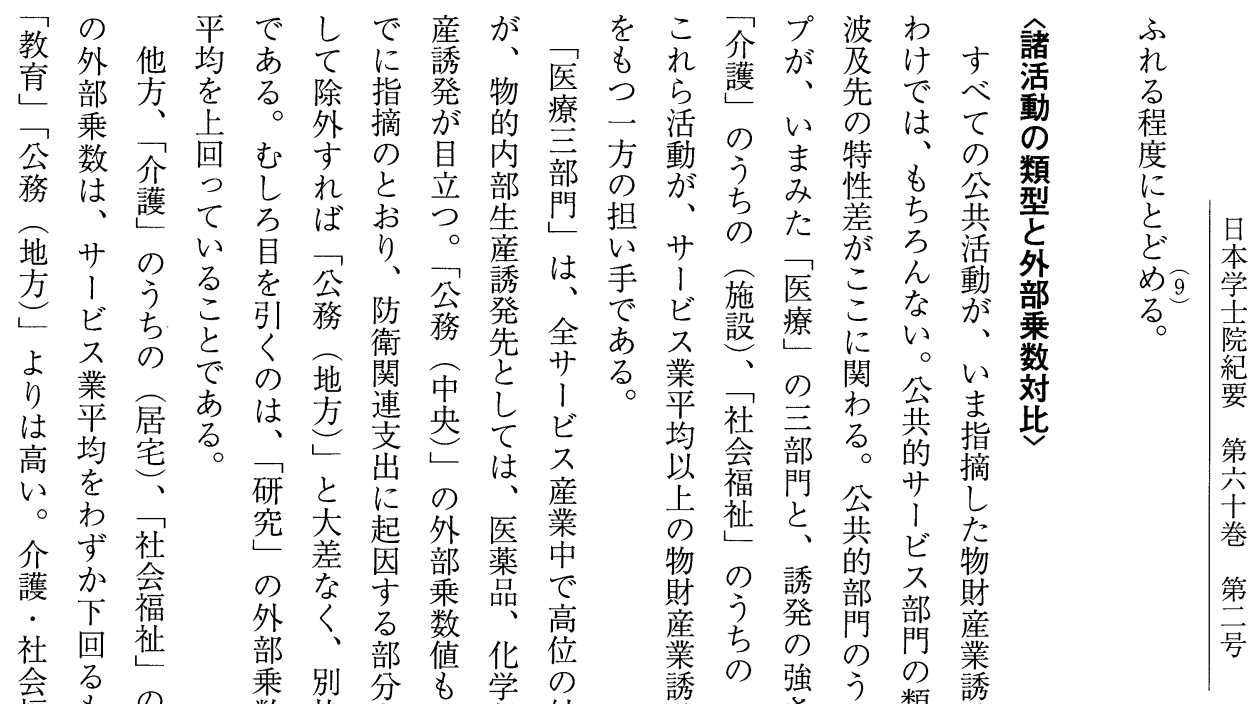

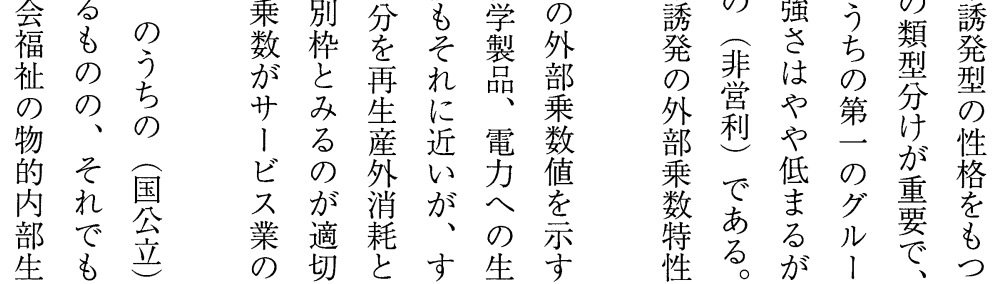

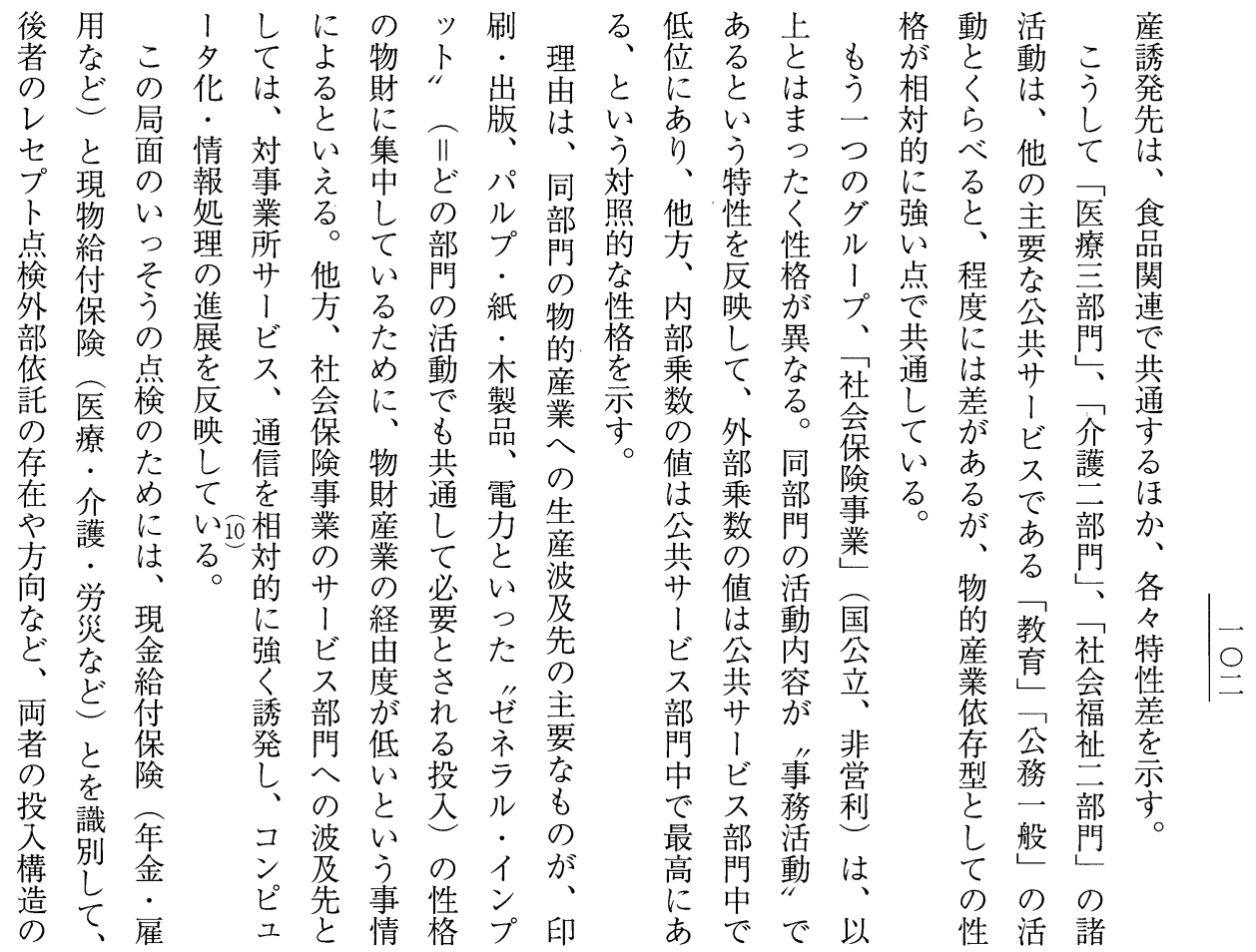






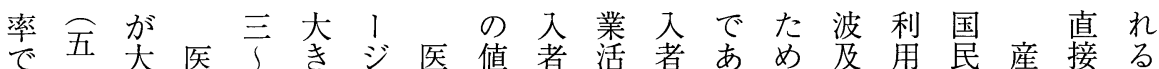

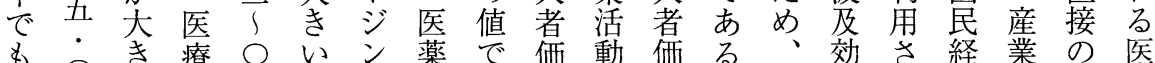

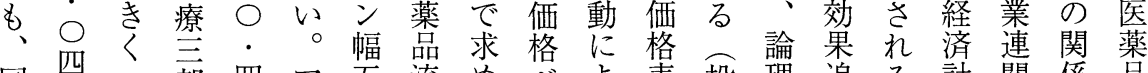
国 四 部四マ吾流め年表投理追る計関係品 公 $\%$ 五門 $\%$ l $\%$ 通 ら文示入上及算表はの

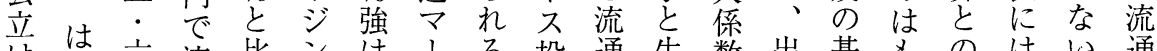

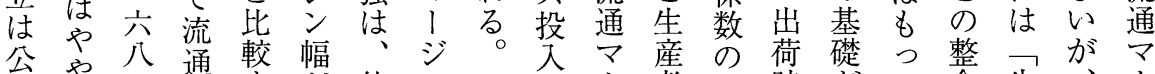

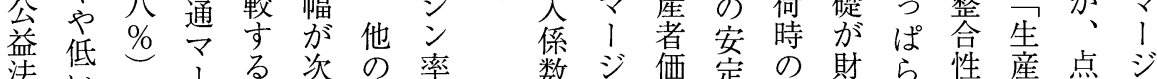

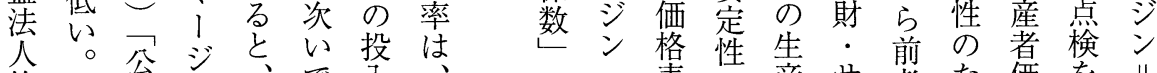

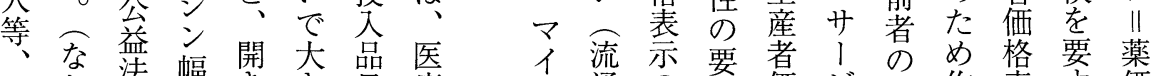

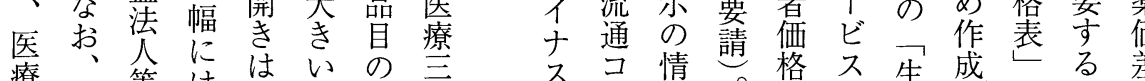
療医等は印食守部

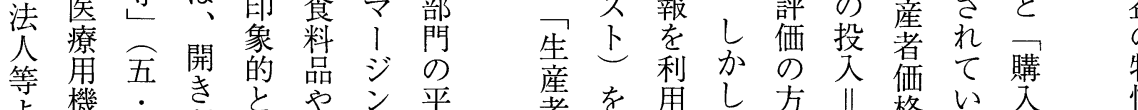

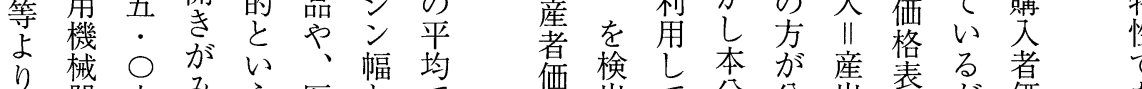

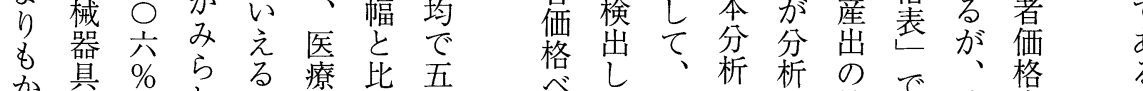

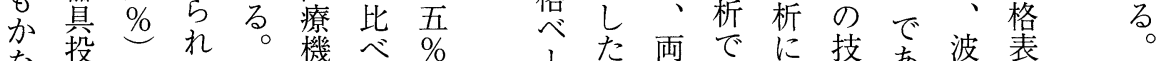

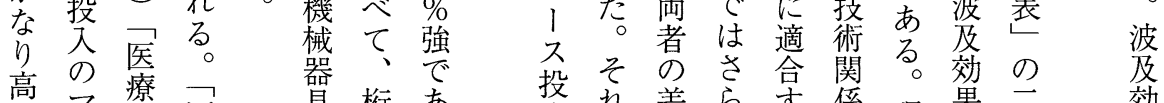

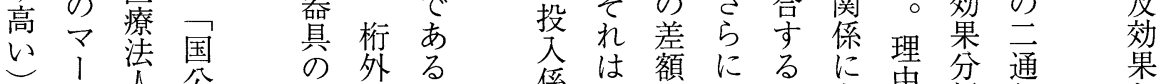

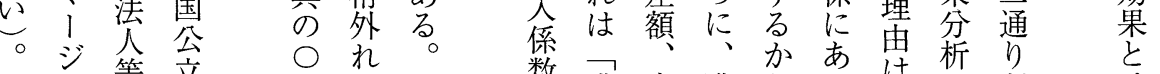

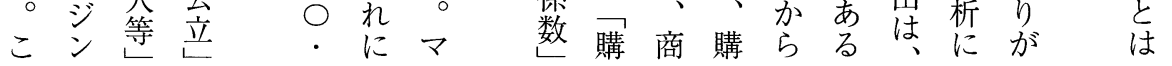

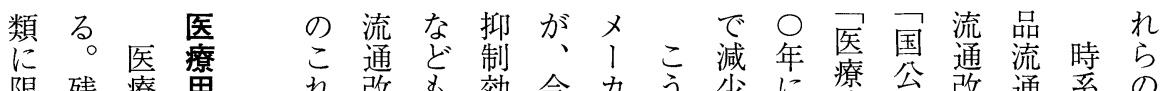

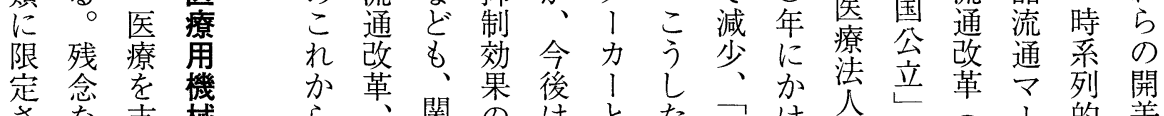

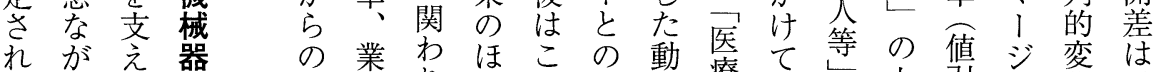

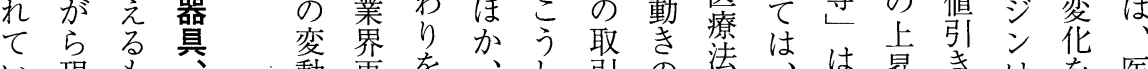

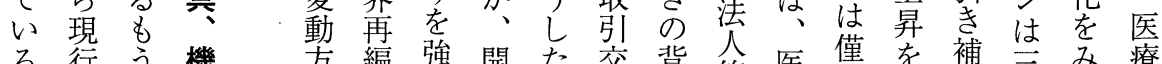

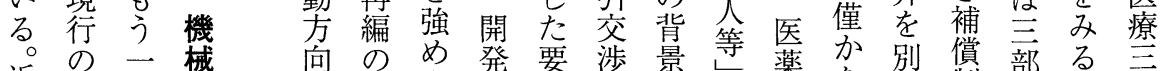

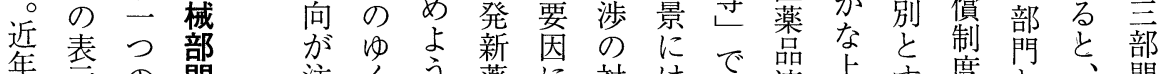

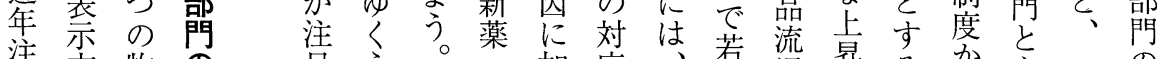

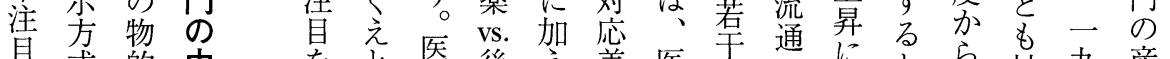

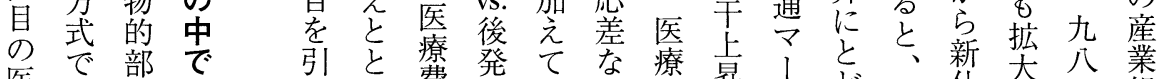

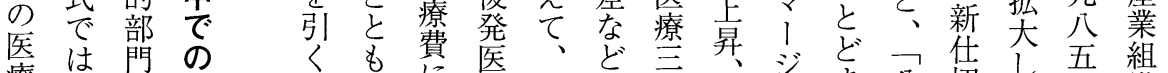

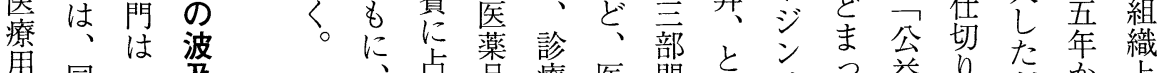

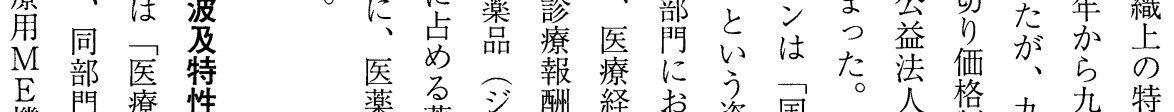

機 の 意 器計機 念範器 高囲悬 瓷精 産

㯰密業

は、器 で

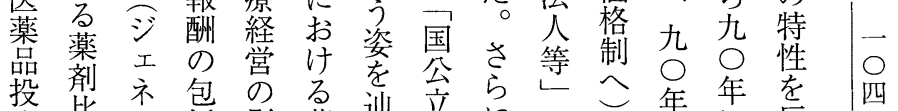

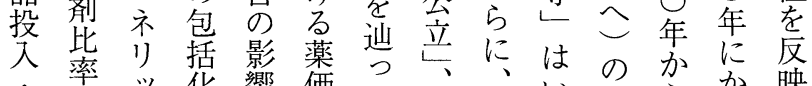
・率ツ化響価ていい影ら 映

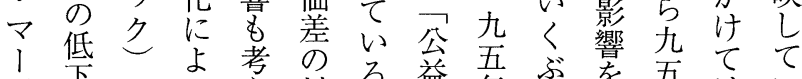

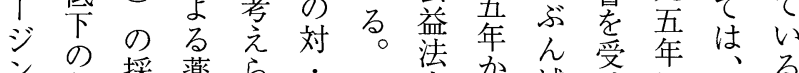

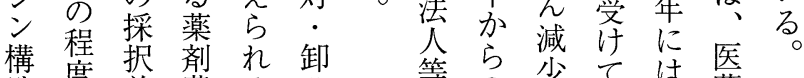

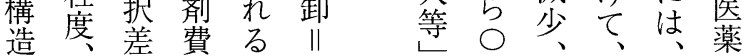




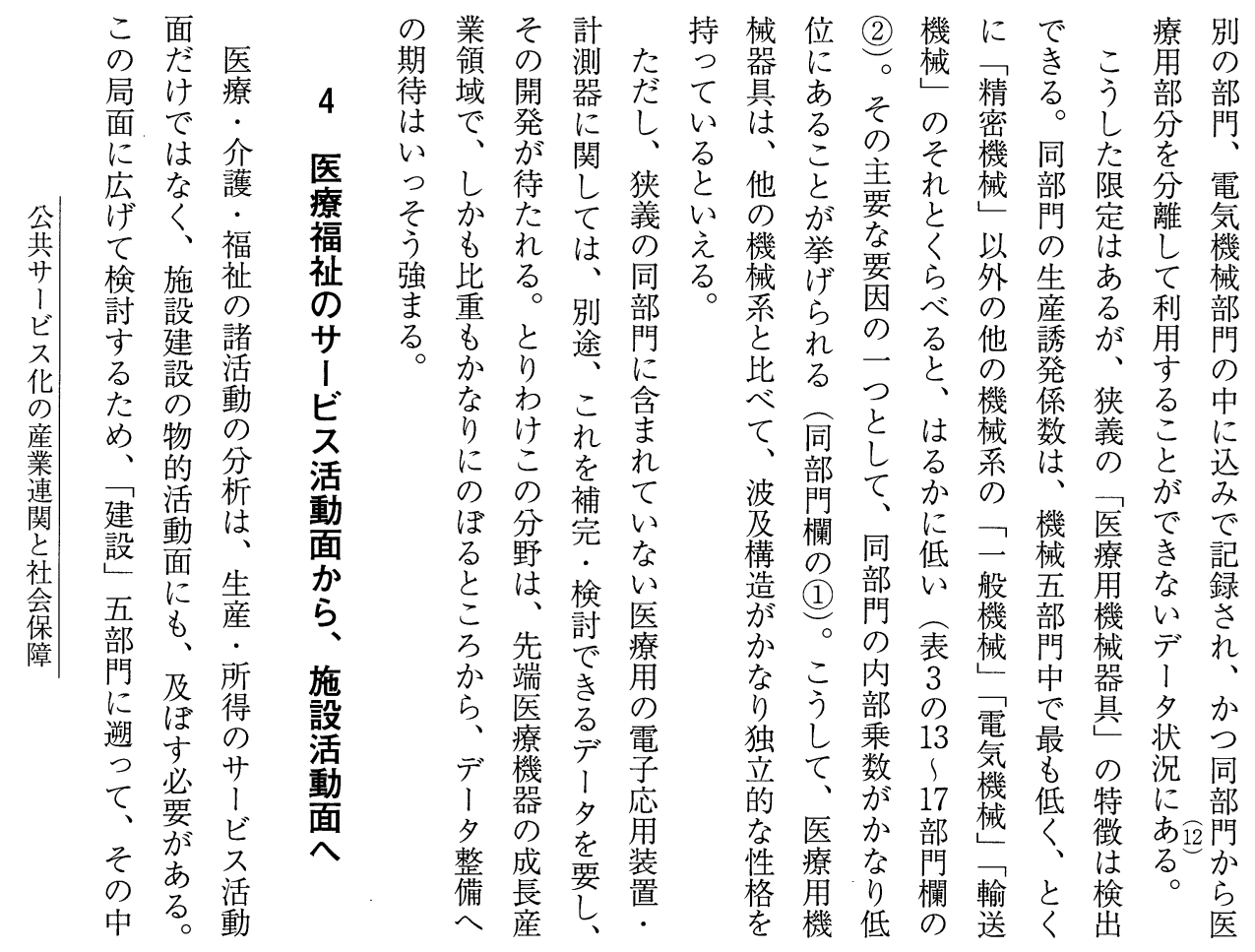

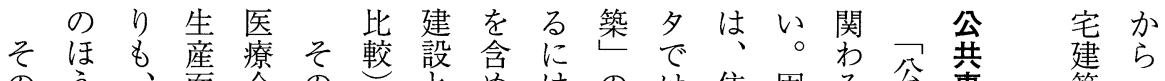

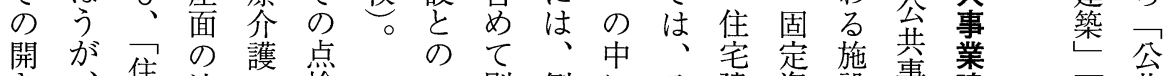

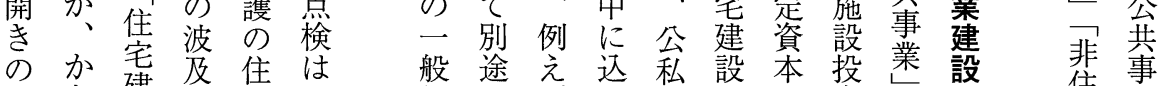

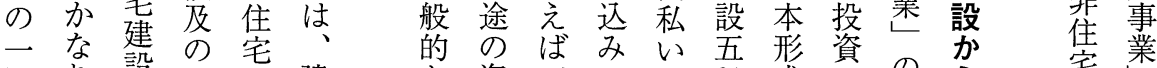

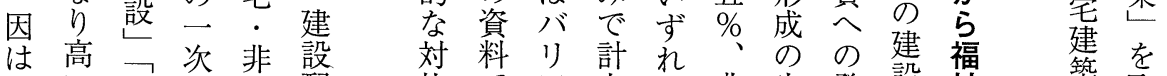

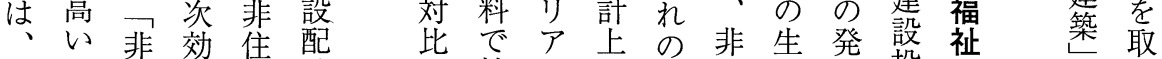

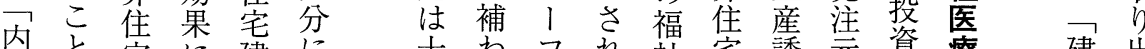
内と宅に建に十わ部方寺祉宅誘元資療建出 部暴建限築扮分なりて医建発は永施設し 数分設定年

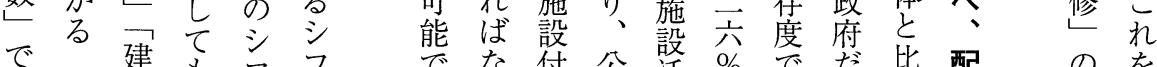
で同設もフブな恷公活\%放た比配のを の同設、市ら带峲動でみけべ分活福

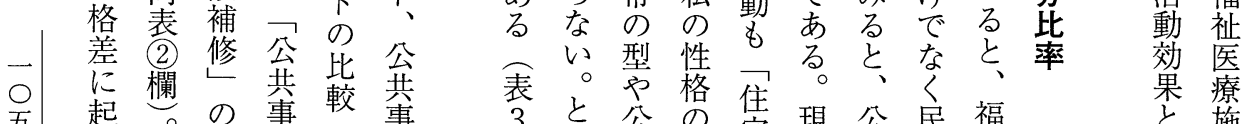

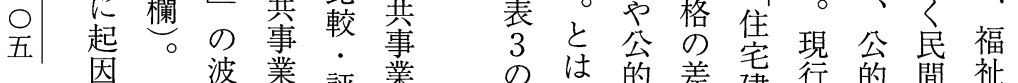
因波業評業 の 乙 㞧效の価建 19 い関孝筑の投の.

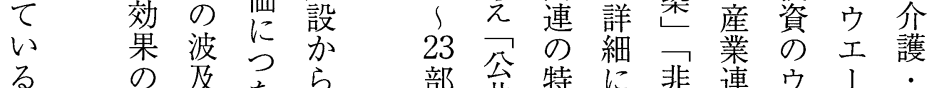
る の度なら、部公特に非連ウ!

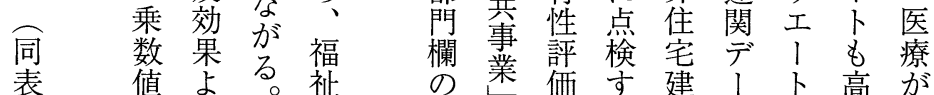
対 施 比に ᄂ 占方 る 


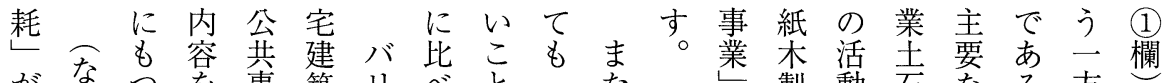

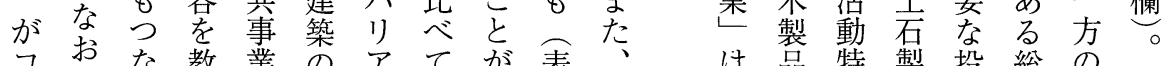
ス社な゙教業のアてが表の所品特製投総の外

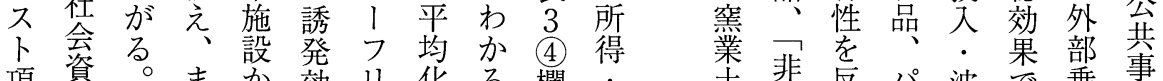

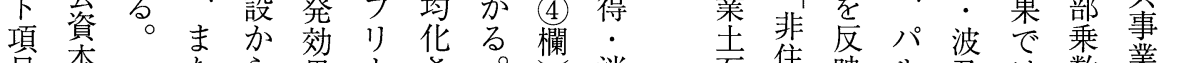

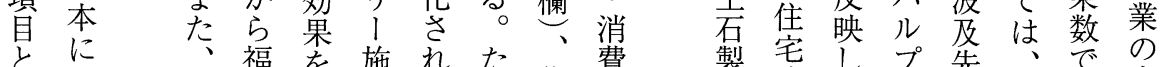

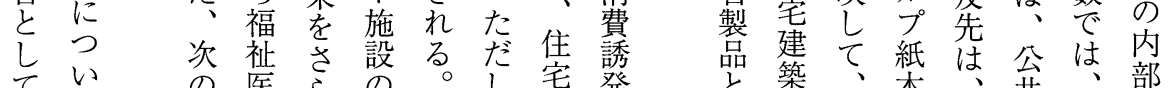
て

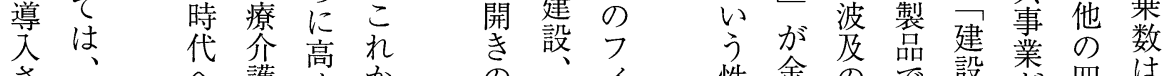

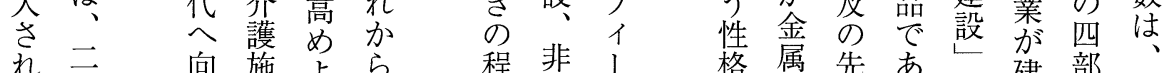

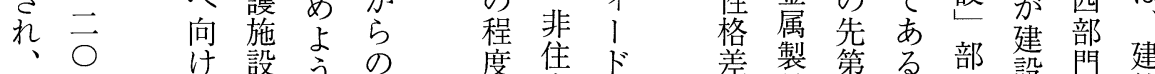

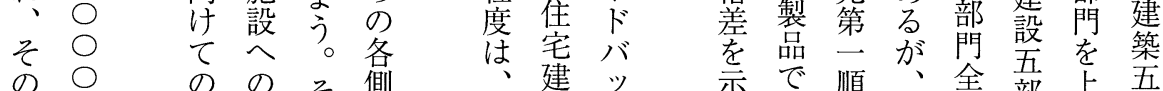

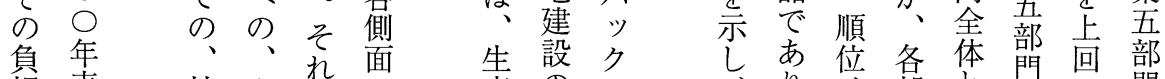

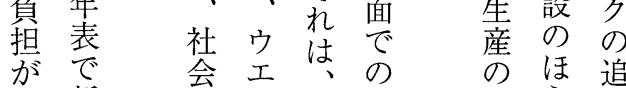

政新資 ! 建充第う加

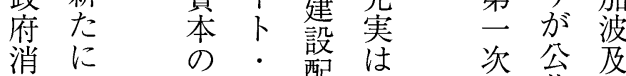
費社再方配分住的共秉 計会成卜に焦菠事数

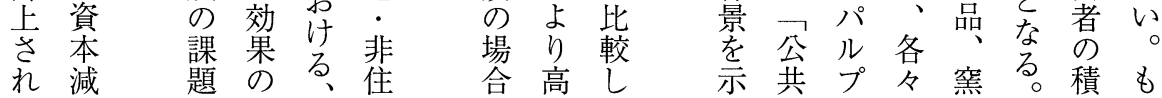

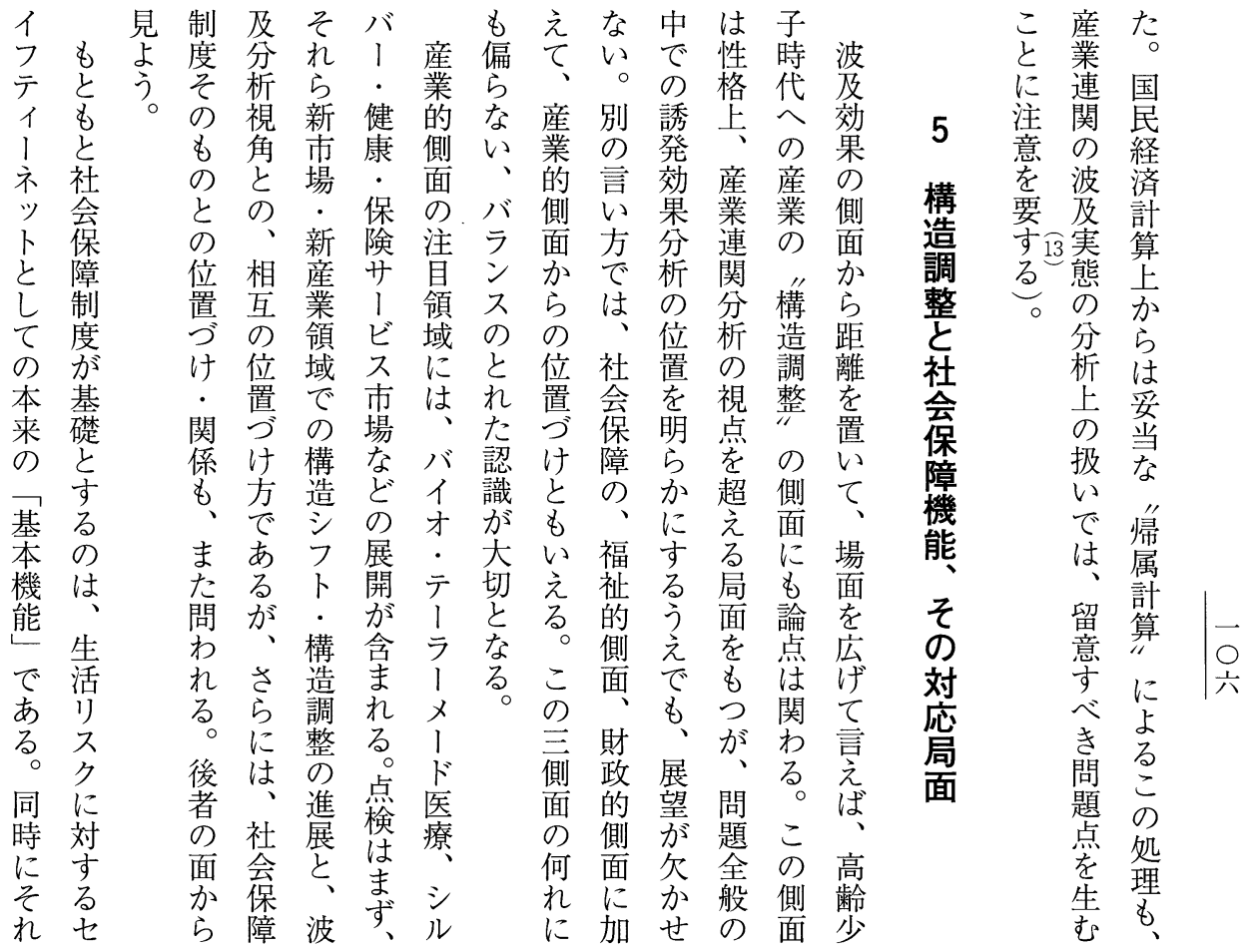




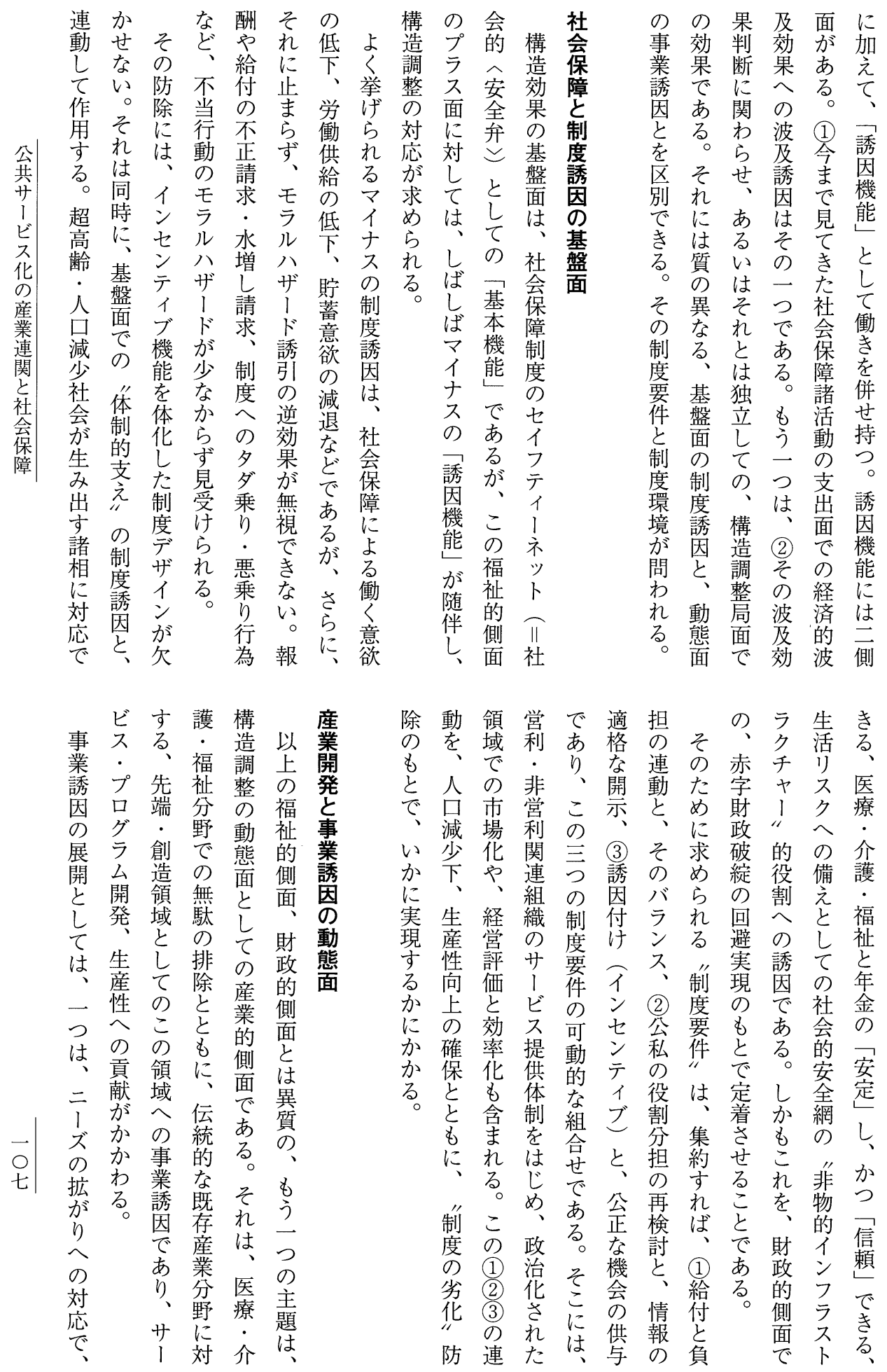




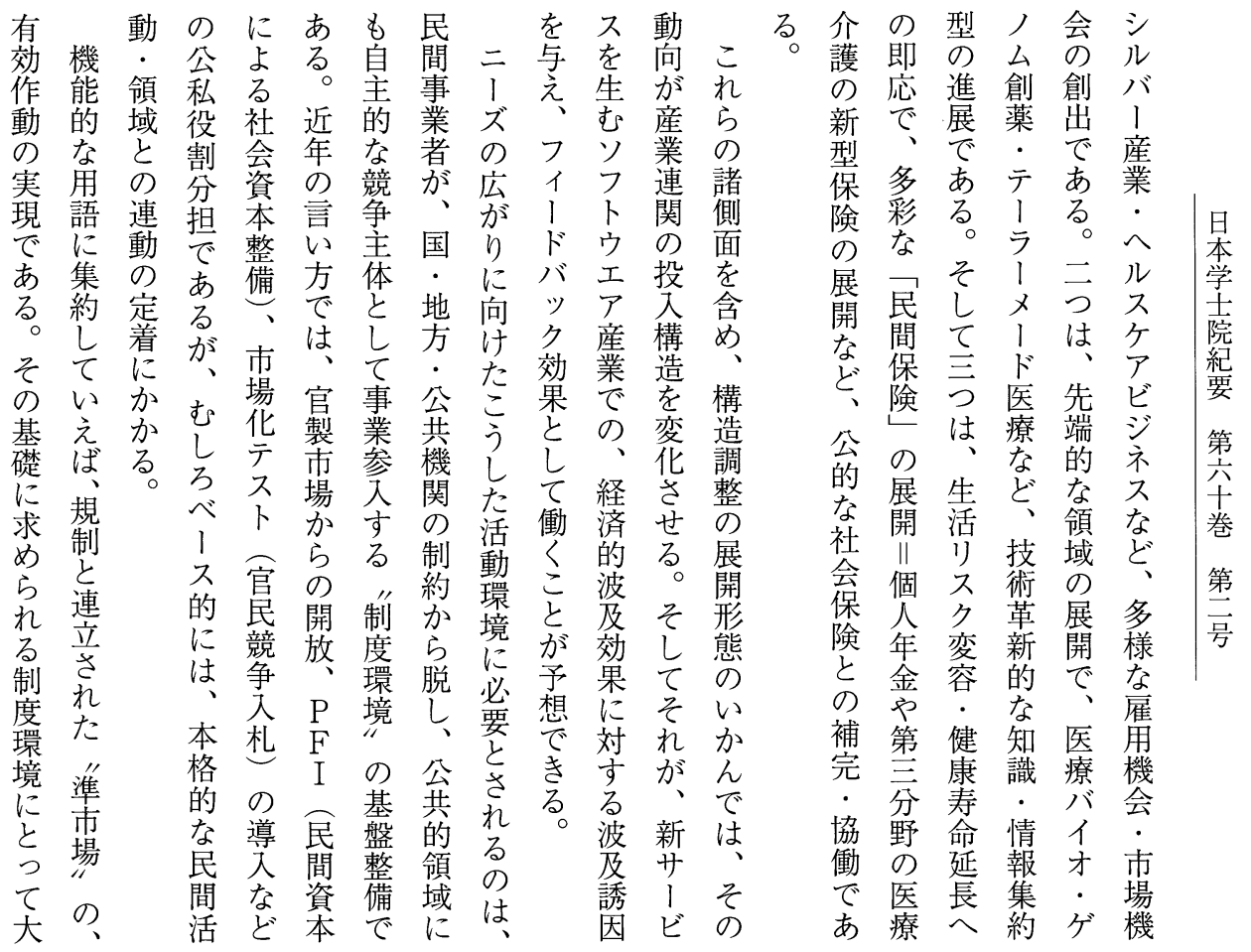

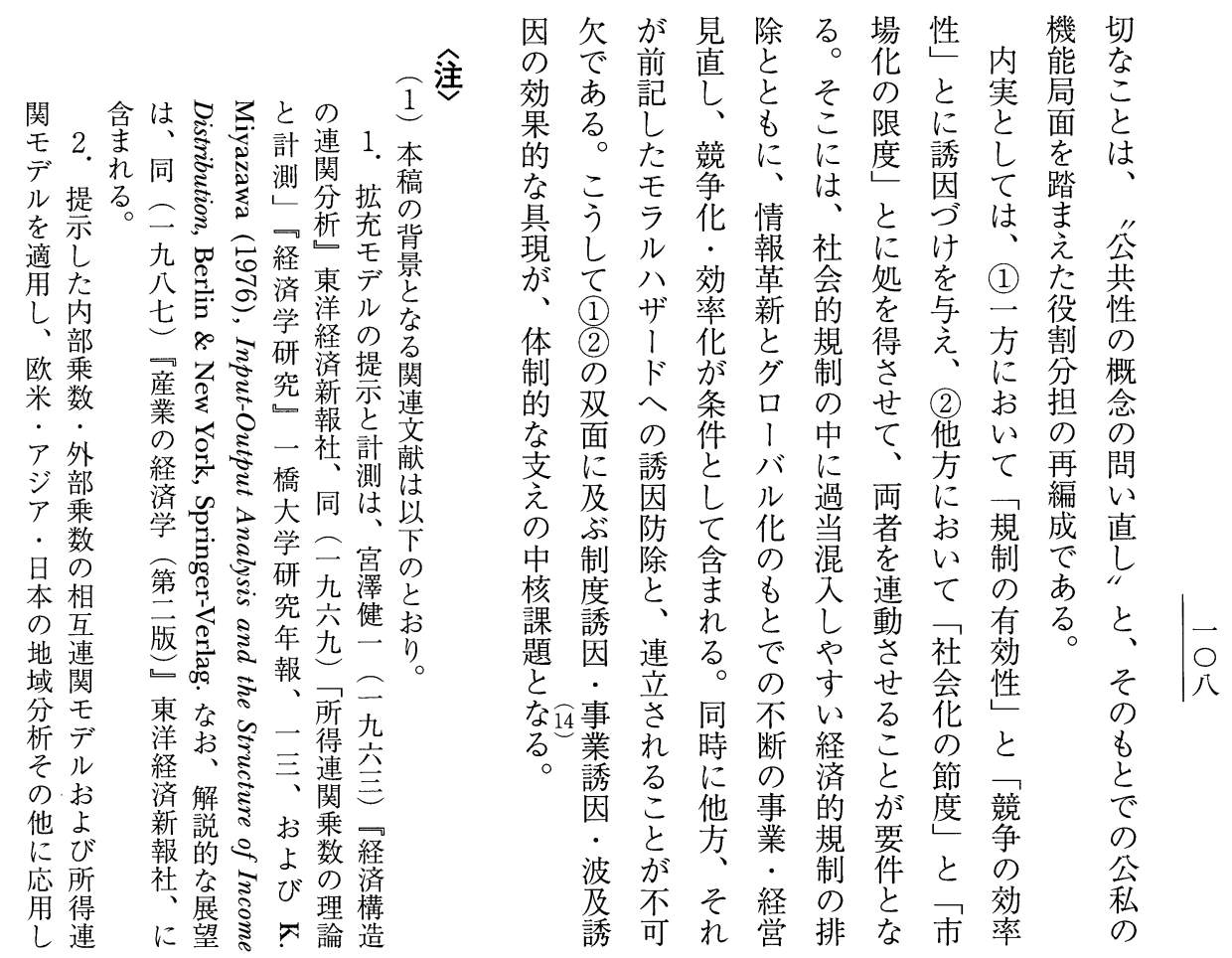




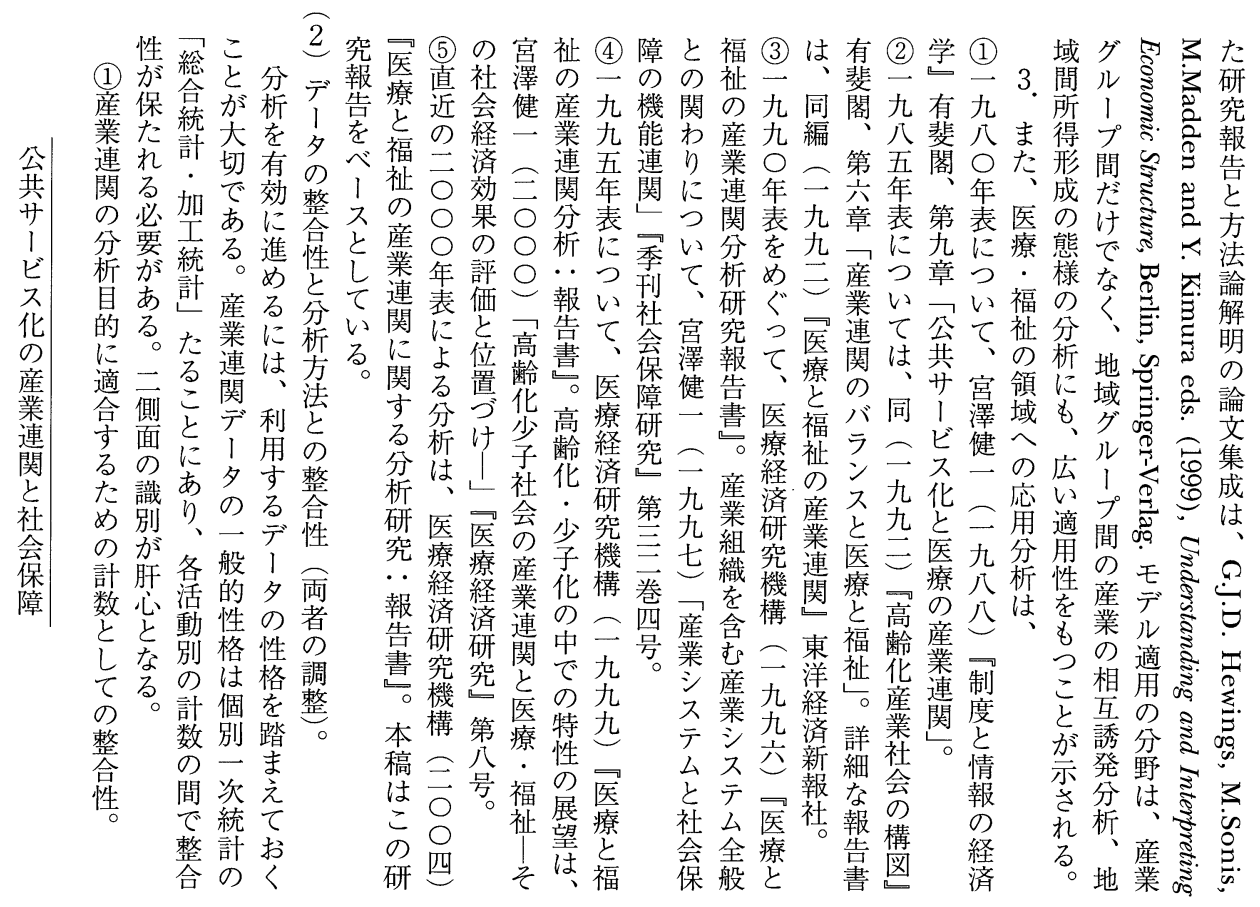

づ府け高を額けでが産のス五年果れす

け专で本め低比そらは医者格生年医局にも以の明、整。

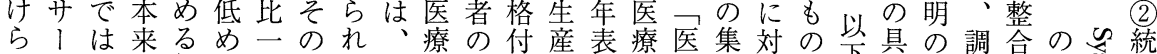
れビ不、偏る五結、ど範け者古療計しはに体た整性関帝計

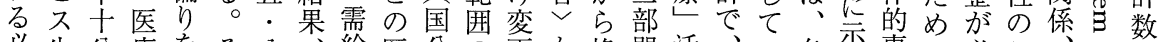
必生分療者々八給医公の更か格門活、马各示事に必己呈值 要産と活招の\%と量療立厳はら付中動本行部波例は要の定乙而

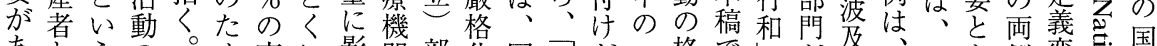

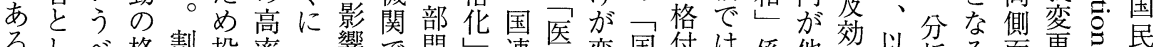

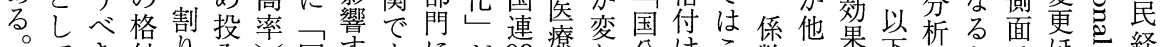
てき付り入一国すもにが93尞わ公けこ数の梁下にケはほ経

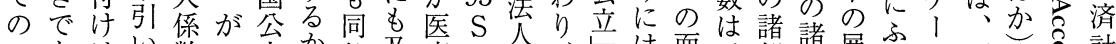

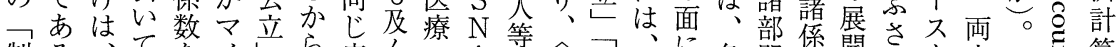

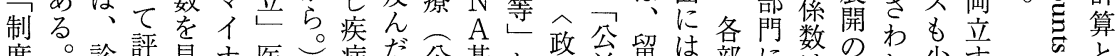

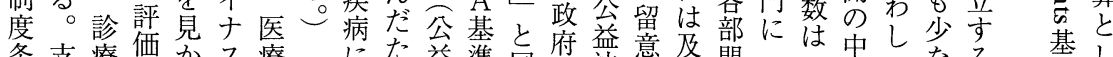

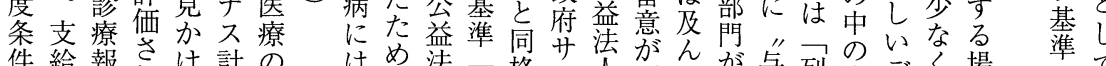
緮酬上場 も独浆高吉合 、る示な㥙 判補さなて、多 断素る期な誘療額 材のつ。発开補 と規価係１助 さ模格数ビ金 れな条を、不 てど件吕産詨 位、上な出産 置政だり額出 はめ法格、资要でが与列注デく場 同で人対の、゙等要で他え和乼テな合 じあ等家、ス寺るいるのる和で多いも

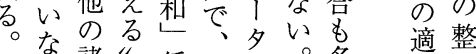

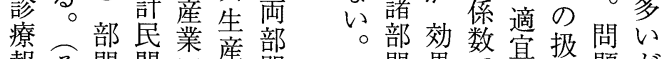

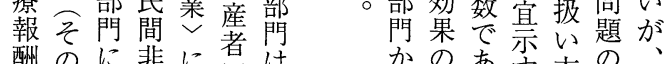
酬のに韭に者睡 で根適営変へ 开拠用利更非前 I...さサさ営回 ビ現れ।れ利の ス行、ビたサ一 が制そス。は九 受度れ生こビ九 ら集あす方特と ”計て必性き 受で、必謤に 惊を要適矛

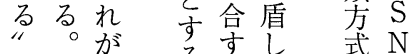
効こ示るるた と A 
ら担支り区 杰託対業はで品がサ食示に関が経氖

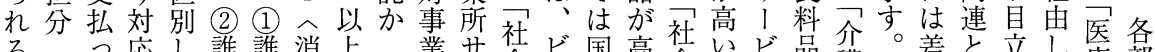

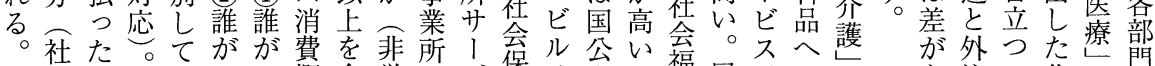
一会個例表”概含営开ビ堡义立。福居、の市注化門

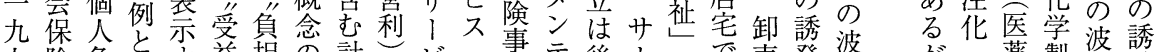

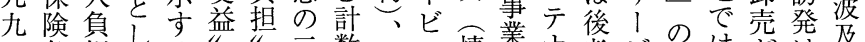
五貣担てる“”言数内情業ナ者ビ波は㤎は先

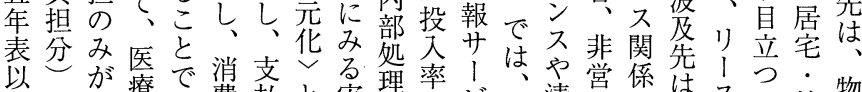

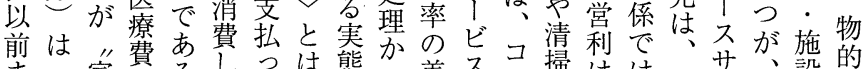

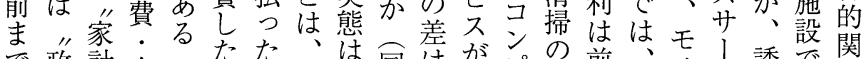

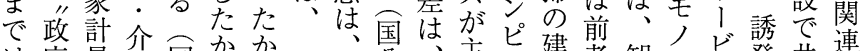
は府最護国かか心付公主筑者卸でビ発共連 、個終謢連のの 両別消に 93 現最 者的費つ $\mathrm{S}$ 㽚最 消㕛心 $\mathrm{N}$ 春綃 も費出て A 繁洎

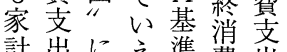
計出にえ準摜出 すに録なとと 心分紫個九存 て離れ公九机 消し、五五 費て 政 直年 劣揭府接表

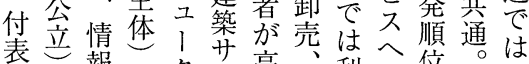

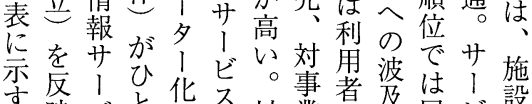

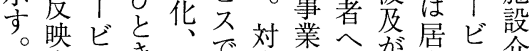
守不

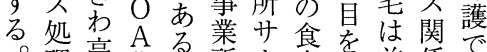
理高化。所।事引者前係の のくを竡提く者息医 主通映に゙た供。施、薬

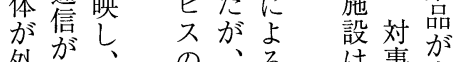
外资、の、るは事架 部恣対主順食後業高 が 薬製及発 勇嵒品先 金ウマ、は波 融卜!そは菠 保ソジし物先 険 I シ て財 のシが電財の 誘ン主力は特 発グ体が医徵 順 。続薬は 位の対く嵒 差進事。妿大 は展業対群要 を所苦次 資反开1拔の 金映ばヒくと 達るス誘次り 方。炙発い 法医高でで の療くは医 相三、薬 違部 情卸品 るげ負によ 依ぐ事体位料者所い。

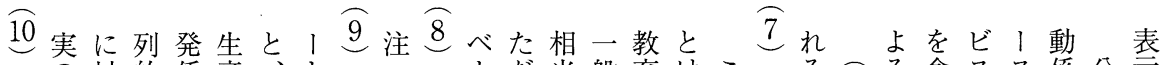

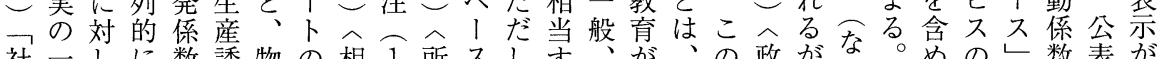

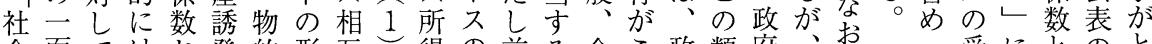
会面ては挍発的形彖得の前る企こ政類府、波 保が、よ係活は誘中連概注。業れ府別消本㨇 険あ後二び数動、発の関念の受一にサは費分及

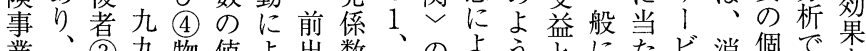
業、(3九物值よ出数、のよう益航だ消個で李

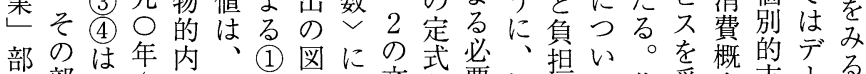

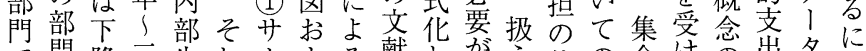
で門隆亏生热による献とが方依の合け出出制は

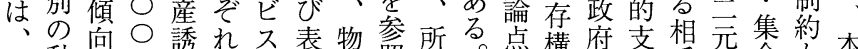

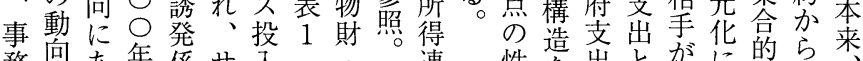
務占古年係サ入 誃関る。数立誘 外念こ前のビ発し! 活をこ帛点活数解 久 動にに(2) り動技説両 は方开がもによ参グ 除卡莌いるび照ル

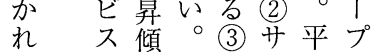

て 経向ま物 | 均間 済にた的ビ值の

保化あ、投 スで交 養のる時入内み流 所内の系誘部るル

連性を出と恃に的ら 関格明では特伴支均完 乗にら、定つ出係界 数よか行受でての数消 のつに政益る必区妏費 計てす、者要要別代係 測はす警が支と別帒数 例 lo そで、定でる いには防で医個 乙相有衛な療別 は応益こい介的

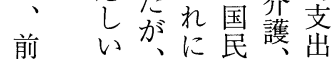
一受にとのと 体給変し表ら と\|換て章れ し 消しの形て て費て なは求消でた さ、め費はて れ家る係—到 る計必数負わ かの要 $v$ 担 ゆ ら直がをべる で接あ算! 移 本自る出 ス 転 稿負なるが支 の担ぜに基出 消分なは本。 費たら、と 係け、現さ 数で医実れ はな療消る 己く: 費 が の 政介の 捉府護一家 え負の受計 方担サ益の 

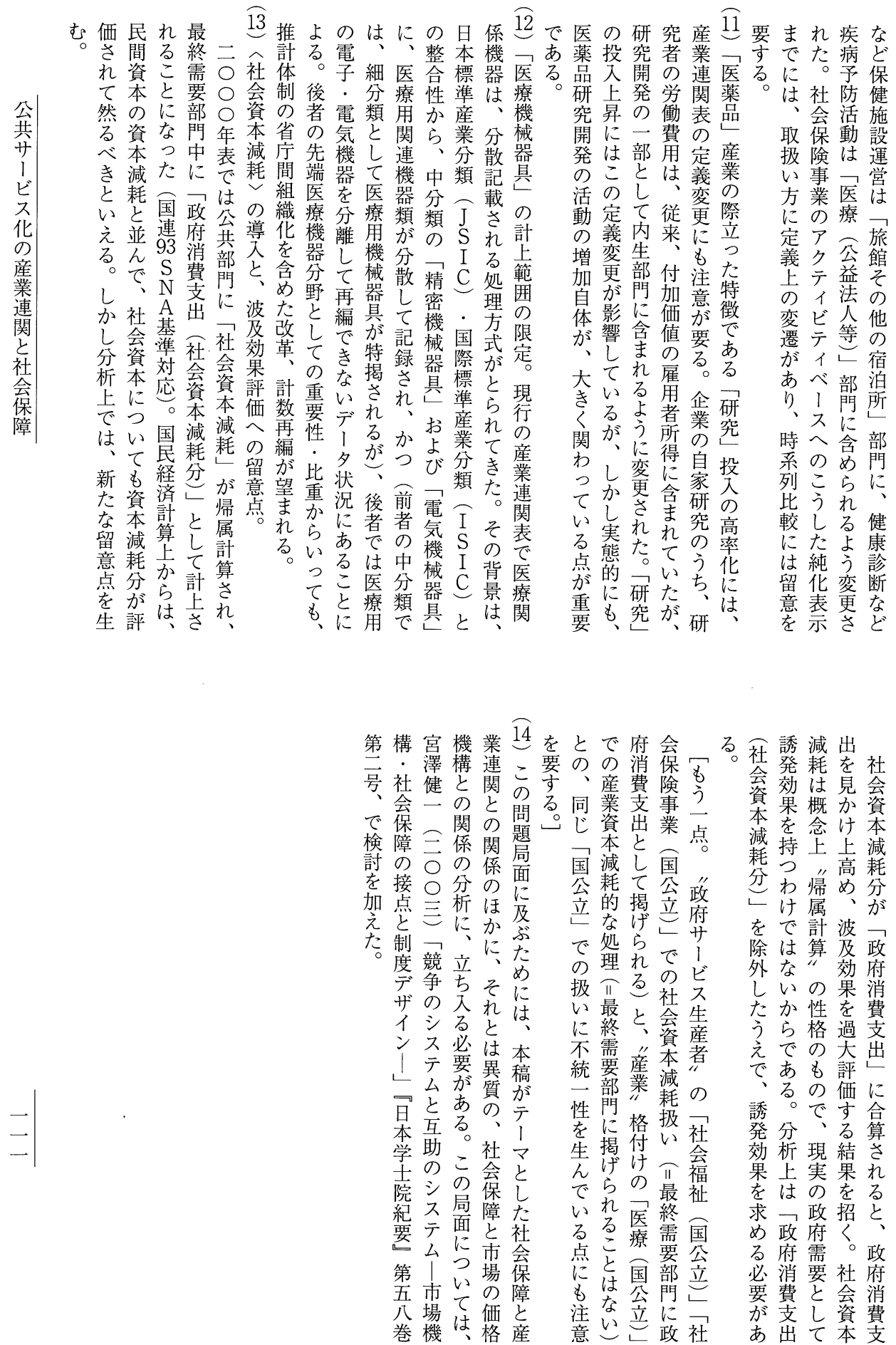
insurance and other new fields function effectively as "quasi-regulated markets" which introduce a competitive environment between the public and private sectors. The way in which these effects manifest themselves will reshape the inter-industry structure, causing a change in the pattern of input-output multiplier effects.

It is the meaning and behavior of these aspects, outlined above, that this analysis seeks to elucidate. 
characteristics between the private and public sectors. A "service-begetsservice" effect (service industry "internal multiplier") is high for private sector services and low for public sector ones. However, the effect of service activity when induced by feedback manufacturing activity (service industry "external multiplier") is stronger in many areas of the public service sector. Medical, care and welfare activities possess this characteristic.

Generally, when compared to those in the private sector, public sector services are more dependent on the manufacture of goods in terms of the combined effects of "internal" and "external" multipliers.

(3) From medical, care and welfare services to facility construction

To look at how public facility construction affects, the multiplier effect of medical, care and welfare facility construction is analyzed comparing with public works. The results show that even when limited to the primary multiplier effect of production, the economic induction effect of housing and non-housing construction and facility repair far exceeds that of public works.

With a growing trend toward barrier-free construction, this induction effect is bound to strengthen. The weight shift in construction apportionment from public works to medical, care and welfare facilities may be seen as linked to a reorganization of social capital.

(4) Adjustment to economic structure and social security

The basic function of social security was originally to provide a safety net against life's risks. Added to this is an "incentive function." Multiplier effect is one such function, but there are several others.

Against the positive side of social security's basic functions, the system can induce a negative side such as various kinds of moral hazards, which must be eliminated. Systematic effort spawned by institutional incentive will be needed to realize a stable and reliable social security system.

Another structual adjustment aspect of the incentive function is the application of creative fields to the medical, care and welfare domain. Silver and health markets, technical innovations in tailor-made health care, private 
them.

(2) Income formation and consumption feedback effect (introduction of income-consumption-production link)

The focus of conventional input-output analysis is on seeking the multiplier effect on the production side of the economy. However, reverberations generated by production activities provide people with income, which induces consumption and, in turn, consumer goods production, feeding full circle back into production activities. I also seek to elucidate this added multiplier effect through the device "incomeconsumption-production link" in terms of the combined effects of submultipliers.

The principal elements of the analysis results are as follows.

(1) Social security vs. public works, within public policy

Social security should not be viewed from only its burden side, but also seen in terms of its expenditure effect. Using the conventional analysis base to compare the induction effect of production, the repercussion effect of medicine, care and welfare would be $10-20 \%$ less than that of public works. This is because no added multiplier effects are induced via income. When adding this income-consumption-production link, the result is reversed: The multiplier effect of medicine, care and welfare exceeds that of public works.

The effect also influences employment. Employment induced through various social security-related activities exceeds that induced by public works in all domains. This is the case even when there is only the primary multiplier effect, with no added effects. The weight shift from public works to social security in government funding is amplifying this multiplier effect.

(2) Medicine, care and welfare amidst expanding private and public services

Birth-rate decline and population aging amidst service sector growth is spurring the expansion of public services, which in turn is affecting the multiplier patterns. Even the same service activity displays different 


\section{Industrial Activity and Social Security in Public Service Economy}

-Economic Repercussions of Medical, Care and Welfare Activities-

Ken'ichi Miyazawa, M. J. A.

With Japan's quicker-than-expected declining birth rate and aging population, the scale of activities in its medical, care and welfare sectors exceeds those of education and research, which are also components of Japan's public domain. This is bringing new issues into questions, including policy-related ones. In providing answers, it will be necessary to investigate the state of the medical, care and welfare sectors, while also taking a look from a wider perspective at the influence and function of these sectors as they interact within the wider economy and society. In elucidating this situation, I use as a tool input-output, or inter-industry, analysis, while attempting to widen its scope.

This extension of input-output analysis is useful in investigating the current situation with its advancing trend toward both a growing service sector and expanding public services. This is particularly applicable to the following two cases.

(1) Inter-effect between goods and services sectors (partitioning off the original multiplier effects)

While conventional input-output analysis seeks to elucidate the results of extreme multiplier effects of reverberations, it fails to elucidate mechanisms of "inter-group induction" between goods and services sectors that lie hidden at the root of such reverberations. Hence, I attempt to analyze and elucidate the "inter-branch connections" between services and goods-producing sectors, both from within the groups and from outside 